\title{
Zagadnienia konserwacji i restauracji iluzjonistycznych dekoracji teatralnych jako malarstwa wielkoformatowego szczególnego typu. Ewolucja postaw i metod
}

\section{Wprowadzenie}

$\mathrm{D}$ awne, iluzjonistyczne malarstwo reprezentowane w kompletach teatralnych „wystaw” jest specyficznym rodzajem malarstwa dużego formatu, tworzonego zgodnie z regułami utrwalonymi w toku 300-letniej tradycji ,sceny włoskiej". Jego znaczenie w obrębie dziedzictwa kulturowego związanego z teatrem od czasów nowożytnych po początek XX w. dostrzeżone zostało dosyć późno, z kolei wartość dla historii malarstwa i jego technik nierzadko po dziś dzień jest niedoceniana. Tymczasem już autor istotnego dla historii technik malarskich XVIII-wiecznego traktatu, Antoine-Joseph Pernety, zauważył, że dekoracja sceniczna polega na ,sztuce oddania, za pomoca perspektywy, malarstwa i sztucznego oświetlenia wszystkich przedmiotów, jakie nam oferuje natura", a samo malarstwo dekoracji teatralnych pozostało w zasadzie jedynym obszarem stosowania techniki niegdyś bardzo popularnej, i dowodzi jej walorów ${ }^{1}$. Jednak w czasach nam współczesnych zaszeregowanie do wytwo-

1 A.-J. Pernety, „Dictionnaire portative de peinture, sculpture et gravure avec un traité pratique des differents manières de peindre", Paris 1757, reprint Gèneve 1972, s. 123 
rów malarstwa dekoracyjnego sprawiło, że niejako automatycznie odmawiano im zarówno jakości artystycznej, jak i technicznej. Zachowane do czasów dzisiejszych zbiory malarskich dekoracji teatralnych dowodza, iż często niesłusznie. W toku prac poświęconych zagadnieniu dalszego trwania tych unikalnych kolekcji, ujmowanego w kategoriach konserwacji zapobiegawczej, przeanalizowane zostały także kwestie związane z działaniami konserwatorskimi i restauratorskimi, jakim je poddawano ${ }^{2}$. W prezentowanym tu zestawieniu ujęto dane dotyczące zabiegów wykonanych od końca lat 50. ubiegłego wieku do czasów obecnych na elementach łącznie jedenastu europejskich kolekcji. Zawierają one zbiory pochodzace z okresu od 2. połowy XVIII wieku po lata 20. wieku XX. W zakresie ograniczonym ramami tematycznymi i objętościowymi artykułu przywołane zostaną kwestie związane z budową i techniką wykonania elementów wystaw scenicznych ${ }^{3}$. Kreśląc rys historyczny za konieczne uznano wskazanie, jak materiałowe uwarunkowania i pełniona funkcja determinuja nie tylko stan, ale i wartości tych zabytkowych obiektów oraz w jaki sposób rozpoznanie ich wpłynęło na przeprowadzone dotąd zabiegi konserwatorskie i ewolucję perspektywy implikującej dobór stosowanych metod i środków.

\section{Technika wykonania, tradycyjne użytkowanie i składowanie a specyfika zniszczeń}

Tworzenie iluzyjnej rzeczywistości ulokowanej w sferze fantazji, zmienność - to zadanie, jakie spełniały malarskie dekoracje teatralne tzw. sceny włoskiej jako oprawa widowisk teatralnych i operowych, wspomagane przez jej ma-

(słownika ), s. XXIV-XXXVI (traktatu). Dostęp w internecie : http://gallica.bnf.fr/ ark:/12148/bpt6k257115

2 E. Szmit-Naud, „Kolekcje dekoracji teatralnych jako wyzwanie dla konserwacji zapobiegawczej na przykładzie dekoracji sceny włoskiej w Europie”, [kps], UMK Toruń, 2013 (rozprawa habilitacyjna), s. 284-292; ss. 1-8 zał. D.

3 Techniczna charakterystyka malarskich iluzjonistycznych dekoracji teatralnych od XVIII wieku po wiek XX jest szerokim i bardzo interesującym zagadnieniem, godnym obszernego oddzielnego omówienia, które planowane jest w ramach odrębnej publikacji, zawierającej rezultaty przeprowadzonych poszukiwań oraz badań wielu elementów różnych kolekcji, przeprowadzonych w latach 2006-2013. Wstępne, już opublikowane informacje dotyczące dekoracji scenicznych z dworskich teatrów francuskich: E. Szmit-Naud, Ilurjonistyczne scenografie teatralne jako sžczególny gatunek malarstwa dekoracyjnego. Technika wykonania, „AUNC Zabytkoznawstwo i Konserwatorstwo”, 38, z. 394, Toruń 2010, s. 143-167. 
szynerię i oświetlenie. Oznaczało to podporządkowanie malarskiej wizji ówczesnej infrastrukturze sceny i wymogom użytkowania. Od XVI wieku po wiek XX dekoracje teatralne tworzone były w sposób, który zapewniał cechy pozwalające sprostać tym szczególnym wymaganiom - żywość barw przy jednocześnie matowej powierzchni, nietworzącej refleksów, możliwość kształtowania obrazu jasnymi i wyraźnie rozgraniczonymi plamami barwnymi sprzyjającymi trompe l'oeil, lekkość i łatwość manipulacji oraz składowania mimo dużego formatu, szybkie tempo wykonania i względnie niską kosztochłonność - istotne wziąwszy pod uwagę wielkie powierzchnie zestawu malowideł i ich żywotność, obliczaną na zaledwie kilka dziesięcioleci - których nie należy jednak utożsamiać z niską jakością.

Wymienione walory, zapewnione dzięki określonej technice wykonania niosły ze sobą zasadniczą wadę - niewielką trwałość, inaczej mówiąc - dużą wrażliwość na niesprzyjające warunki, a przynajmniej w części takie generowało użytkowanie i tradycyjne przechowywanie. Sposób konstrukcji i użyte materiały - drewniane proste krosna, płótno, papier, rzadziej samo drewno - determinują niską wytrzymałość mechaniczną i zarazem łatwopalność. Jednocześnie higroskopijność tych materiałów oznacza wrażliwość na zmienne warunki klimatyczne, a złożona struktura implikuje różnorodność reakcji, zależnie od jakości, rodzaju i stanu poszczególnych warstw. Naprężenia, wynikające z montażu na nieregulowanych krosnach oraz z masy płócien i ich zwieszania oznaczają skłonność do deformacji. Stosowane spoiwa - od służącego do przymocowania papierowych osłon odwroci po warstwę malarską, zawierające głównie naturalne kleje, zachowują, w większości wypadków, rozpuszczalność w wodzie, więc bezpośredni z nią kontakt grozi unicestwieniem malowideł. Natura spoiw czyni je wrażliwymi na atak mikroorganizmów, a porowata struktura i powierzchnia warstw malarskich sprzyja zakurzeniu i osadzaniu kopcia.

Używanie na scenie oznaczało w trakcie tzw. zmian otwartych, czyli wymiany scenerii na oczach widzów, gwałtowne poruszanie i przemieszczanie czy to za pomocą maszynerii, z którą dekoracje były odpowiednio sprzężone (il. 1), czy też ręcznie, w teatrach mniej wyposażonych oraz w czasie, gdy zmiany otwarte przestały być popularne, tj. w XIX wieku. W przypadku elementów na krosnach np. kulis czy fermón kilkumetrowej wysokości, oznaczało to nagle przesuwanie w płaszczyźnie poziomej bądź pionowej. Ele- 
menty zwieszane - prospek.ty i sufity (in. paludamenty, fartuchy), a później także przeciecia podczas zmiany wystawy były gwałtownie podnoszone i składane, np. w „harmonijkę” czy na pół oraz nagle rozwijane i opuszczane lub rozkładane ${ }^{4}$. Wszystkie te zmiany składowych wystawy zachodziły jednocześnie, nie zawsze bezkolizyjnie (il. 2).

Dodatkowe ryzyko zniszczeń stwarzały mocowane za dekoracjami maszty, ruchome listwy i mosty świetlne, ze źródłami światła o żywym płomieniu (aż do momentu wprowadzenia oświetlenia elektrycznego, tj. od połowy XIX w.), z mobilnymi osłonami regulującymi oświetlenie. Ponadto zagrożenie niszczeniem z przyczyn mechanicznych stwarzała obecność aktorów, śpiewaków czy baletu, czasem też statystów poruszających się wśród elementów dekoracji, wchodzących w drzwi prak.tykowanych kulis, prospektów pośrednich bądź fermów, używających praktykabli, a w końcu XVII wieku - jeszcze widzów, zwyczajowo obecnych na scenie...5

Część uszkodzeń powstawała także w trakcie tradycyjnego składowania i transportu dekoracji. Niepotrzebne na scenie elementy wystawy przechowywane były w tzw. stosach (fr. tas) ${ }^{6}$, oparte jedne o drugie, przy ścianach zascenia, bądź w boksach, zwanych też kojcami, lokowanych najczęściej w tylnej partii zascenia, a stanowiących prostą konstrukcję przegród z krawędziaków, pomiędzy którymi ustawiano ciasno, pionowo, opierając o siebie nawzajem, wszelkie sztywne elementy scenerii (il. 3). Części wiotkie - sufity, prospekty, przecięcia - o ile wysokość nadscenia na to pozwalała, mo-

4 Zagadnienia związane $\mathrm{z}$ teatralną maszynerią wykraczaja poza ramy narzucone tematyką niniejszego opracowania. Podstawy znaleźć można m.in. w: przedmowie Zbigniewa Raszewskiego do dzieła: Marie-Antoinette Allévy-Viala. Inscenizacja romantyczna we Francji, Warszawa 1958; J. Furtenbach, O budowie teatrów, Wrocław 1958, s. 14-19. Więcej informacji np. w: K.-D. Reus, M. Lerner, Faszination der Bühne, Barockes Welttheater in Bayreuth, Barocke Bühnentechnik in Europa, Bayreuth 2001 lub w publikacjach. Franka Mohlera, np.: The Upper Inner Stage in the Illusionistic Theatre, Theatre Design \& Technology, 2012, 48, nr. 2 - http://tdt. usitt.org/GetPDF.aspx?PDF=48-2upperinnerstage. Animacje zmian scenicznych tego autora: http://spectacle.appstate.edu/models/ (14.03.2015).

5 Historia teatru, red. J. R. Brown, Warszawa 1999, s. 247-29. Już trzy wieki wcześniej Sabbatini zwraca uwage na zniszczenia dekoracji, głównie dziury i rozdarcia, powstające, jak z opisu wynika, nieprzypadkowo (wykonywane przez ciekawskich widzów) - N. Sabbattini, Pratique pour fabriquer scènes et machines de théatre, Ravenne 1638 (wydanie francuskie wg reedycji faksymilowej z 1926 r. w Weimarze), Neuchâtel 1942, s. 16.

${ }_{6}^{6}$ A. Bataile, Lexique de la machinerie théatrale, Paris 1989, s. 105. 
gły być podciagane do sznurowni i pozostawiane tam w normalnym położeniu albo dodatkowo podwieszone w złożeniu „portfelowym” bądź „na pół”, albo podciagnięte i kilkakrotnie harmonijkowo złożone ${ }^{7}$. W przypadku niewystraczającej wysokości nadscenia podciagnięte prospekty były przechowywane zwinięte. Najczęściej pozostawiano w ten sposób na poziomie sznurowni zwieszane elementy mystaw, które aktualnie użytkowano. Pozostałe były zwijane wokół własnych sztang (czyli dragów do których były mocowane i zwieszane) i składane na pomostach nadscenia, w tylnej części, nierzadko jedne na drugich. Był to system stosowany powszechnie, także w dużych teatrach operowych dysponujących magazynami, ale strefa zaadaptowana $\mathrm{w}$ przestrzeni scenicznej na magazynowanie dekoracji $\mathrm{w}$ teatrach dworskich często była bardzo ciasna, wykrojona z części zascenia i nadscenia, czasem bez jakiegokolwiek wyposażenia ułatwiającego składowanie i porządkowanie elementów dekoracji. W przypadku dworskich teatrów królewskich czy książęcych, czy też magnackich, zestawy dekoracji przypisane były nie do konkretnej sceny, choć dla niej je tworzono, ale do dworskiego teatru, jako instytucji, i mogły być wykorzystywane na różnych scenach o zbliżonych proporcjach. Transport tych wielkoformatowych malowideł z malarni do teatru nie był jedyna podróża, jaką odbywały. W ustalonych zwyczajem okresach przewożono je z jednego teatru do drugiego, w ślad za przemieszczającym się dworem ${ }^{8}$. W ten sposób na przykład do teatru Marii Antoniny w Wersalu trafiła już w XIX stuleciu, gdy był dworskim teatrem Ludwika - Filipa, najstarsza zachowana, XVIII-wieczna dekoracja Światyni Minerny z teatru w Fontainebleau, a inne sceniczne mystawy $\mathrm{z}$ tego teatru przewieziono do dworskiego teatru w Compiègne. Powodem przemieszczania całych zbiorów dekoracji dworskich teatrów mogła być likwidacja niektórych z nich, czego przykładu dostarczają losy teatrów palatyna Wirtembergii ${ }^{9}$ oraz kolekcje szwedzkich teatrów królewskich, obec-

Animacja: http://spectacle.appstate.edu/news/court-theatre-cesky-krumlov (14.03.2015).

8 Dla teatru w Trianon w 1784 roku zostały wybrane dekoracje teatrów dworskich w Choisy i Fontainebleau - D. Lauvernier, Le Temple de Minerve: un décor de scène du fonds des Menus Plaisirs datant de 1754, „Le bulletin de la Société De l'Histoire de l'Art Français” 1992, s. 136, 141.

9 W dworskim teatrze w Ludwigsburgu znalazły się - i zostały zaadaptowane do użytkowania na scenie - dekoracje z rozebranych teatrów w Grafeneck i Teinach - S. Esser, 
nie w Drottningholm i Gripsholm ${ }^{10}$, czy teatrów rodu Schwarzenbergów w przypadku z Českiego Krumlova. Transport dekoracji - z malarni do teatru i pomiędzy teatrami - odbywał się na wozach zaprzężonych w konie, bądź, jak w przypadku dworu szwedzkiego - także drogą morską.

Zniszczenia powstające $\mathrm{w}$ toku eksploatacji, jak i trwania w zapomnieniu, co było udziałem zachowanych do dziś kolekcji, to deformacje i rozdarcia wynikłe z osłabienia struktury płócien (il. 4) wskutek m.in. własnego ciężaru, złamania konstrukcji, zarysowania i przetarcia warstw malarskich, straty malarskiej materii spowodowane zalaniem (il. 5), zawilgoceniem i rozkładem spoiwa wskutek rozwoju mikroorganizmów lub wskutek pracy podłoża, zabrudzenia o powierzchniowym bądź trwałym charakterze. Ten krótki opis zniszczeń, sprowadzony do określenia ich rodzaju, służąc wskazaniu powodu wykonywanych zabiegów konserwatorskich opisanych w dalszej części tekstu, jedynie sygnalizuje problematykę stanu zachowania malowideł będących przedmiotem obecnej relacji. Pełna charakterystyka tych zagadnień znajdzie miejsce w odrębnej publikacji. W ramach niniejszej zasadnym wydaje się podkreślenie, że znaczna część zniszczeń to odciśnięty w materii ślad pełnionej funkcji, świadczący o tożsamości tych dzieł.

\section{Zainteresowanie}

\section{malarskimi dekoracjami scenicznymi jako dziedzictwem związanym $\mathrm{z}$ teatrem}

Spoglądając na losy zabytkowych teatrów, które weszły w wiek XX z niemal kompletnym scenicznym wyposażeniem, zauważyć można, że zain-

Wohin mit grossformatigen Bühnenbildern? Konservierung, Deponierung und künftige Präsentation. Der historischen Bühnenbilder aus dem ludwigsburger Schlosstheater, [w:] Das Schloss und seine Ausstattung als Denkmalpflegerische Aufgabe, Eine Tagung des Deutschen Nationalkomitees von ICOMOS und des Facharbeitskreises Schlösser und Gärten in Deutschland, Wörlitz, 5.-8. Oktober 1994, ICOMOS, Hefte des Deutschen Nationalkomitees, 1995, 16, s. 81.

10 Do Drottningholm, już w XVIII wieku trafily dekoracje z teatru Bolhuset rozebranego w 1792 roku, potem kolejne - Barbro Stribolt, Scenery from Swedish court theatres: Drottningholm, Gripsholm, Värnamo 2002, s. 33. 
teresowanie samymi teatrami, owocujące przedsięwzięciami służącymi ich ratowaniu, pojawiło się już w okresie międzywojennym ${ }^{11}$. W tym czasie działania świadczące o uwadze skierowanej ku dawnej malarskiej oprawie sceny należały do wyjątków - pierwsze zostały podjęte w Szwecji, dotycząc zbiorów Drottningholm, kolejne już po II wojnie światowej, w latach 50 . w Czechach w Českim Krumlovie i Litomyšlu. Powszechne bardziej metodyczne postępowanie ukierunkowane na ochronę tego rodzaju zbiorów pojawiło się dopiero w ostatniej ćwierci XX wieku i na początku obecnego stulecia.

Szczególne ożywienie datuje się od końca lat 90., co znalazło wyraz w zawiązywaniu stowarzyszeń i organizacji konferencji poświęcanych, przynajmniej częściowo, zagadnieniom materialnego dziedzictwa historycznych teatrów i ich wyposażenia. Jako przykłady wymienić można: zawiązanie w 1992 roku Fundacji Barokowego Teatru w Českim Krumlovie, od 2001 organizującej corocznie międzynarodowe konferencje pod hasłem Świat barokowego teatru, na których prócz formalnych tematów poruszane są także zagadnienia związane $z$ wyposażeniem technicznym scen i dekoracja, powstanie we Francji ATI - Association des Théâtres à l'Italienne (Stowarzyszenie Teatrów Sceny Włoskiej) w 1994 r. $^{12}$, konferencję dotyczącą teatrów dworskich i prywatnych w Compiègne w 1996 r., skutkująca m.in. utworzeniem międzynarodowego stowarzyszenia, sesję Opernbauten des Barock (Barokowe budynki operowe) niemieckiego komitetu narodowego ICOMOS w Bayreuth w 1998 r. czy 23 kongres SIBMAS Performing Arts: National Heritage and Information w 2000 r. ${ }^{13}$ Lokalną inicjatywą była działalność Stowarzyszenia Milislav w latach 2001-2005 na rzecz litomyskiego teatru zamkowego i jego kolekcji. W 2002 r. odbyła się w Bad Lauchstaedt

11 Pełny opis zagadnień dotyczących ewolucji postawy względem malarskich dekoracji scenicznych do momentu dostrzeżenia w nich części dziedzictwa kulturowego zawarto w przywoływanej rozprawie habilitacyjnej - E. Szmit-Naud, Kolekecje dekoracji..., s. 243-284, 315-322.

12 ATI, wspierane przez Ministerstwo Kultury i Komunikacji, zrzesza około czterdziestu tradycyjnych teatrów, tj. o scenie „włoskiej”; ma pomóc tym instytucjom w pełnieniu podwójnej misji: kulturalnej związanej z działalnością teatralną i misją ochrony dziedzictwa, które te teatry reprezentuja.

13 SIBMAS - Société Internationale des Bibliothèques et des Musées des Arts du Spectacle. 
w Niemczech międzynarodowa konferencja dotycząca kwestii zachowania historycznych teatrów ${ }^{14}$. W jej konkluzjach zadeklarowano intencję utworzenia międzynarodowego stowarzyszenia umożliwiającego dokonanie w Europie ich spisu, wymianę doświadczeń i współpracę w budowaniu świadomości dotyczącej eksploatacji niestojącej w sprzeczności z dążeniem do zachowania tego dziedzictwa. W efekcie w 2003 r. założone zostało międzynarodowe Stowarzyszenie Teatrów Historycznych w Europie PERSPECTIV, które wspiera badania i restaurację zabytkowych teatrów, popularyzuje wiedzę na ich temat i organizuje kongresy od $2009 \mathrm{r}^{15}$ Do stowarzyszenia należy większość europejskich historycznych teatrów.

Działania dotyczące historycznych teatrów, do momentu uznania za cel zachowania malarskiego wyposażenia ich scen, odzwierciedlaja ewolucję w postrzeganiu tych iluzjonistycznych zabytkowych dekoracji. Długo pozostawały one na marginesie zainteresowań bądź w niewidocznym tle. Początkowo to budynki teatralne, widownie, o typowej dla danej epoki formie i wystroju zdawały się wszystkim, co oznaczać mogło zabytkowy teatr, tym bardziej ceniony, im wydatniej reprezentacyjny charakter mu w przeszłości nadano. Pozostałym, nie tak jawnie spektakularnym składowym teatralnych wnętrz, poświęcano często znacznie mniej uwagi. Zainteresowanie historycznym widowiskiem teatralnym czy operowym jako takim, spowodowało, że tam, gdzie zdołało przetrwać pełne wyposażenie sceny - i dekoracje, i mechanizmy je obsługujące $-\mathrm{z}$ dużą atencja zaczęto traktować autentyczną dawną sceniczną maszynerię. Wydaje się, że w takich wypadkach nierzadko w malarskich sceneriach widziano element jej podporządkowany, skupiając uwage na efekcie zmiany otwartej i innych możliwościach wywodzącej się z baroku maszynerii. Niemniej jednak iluzjonistyczne malarskie dekoracje zostały zauważone jako teatralna spuścizna minionej epoki, godna zachowania.

14 W teatrze Goethego, z 1802 roku, z odrestaurowaną i zrekonstruowaną maszynerią, niestety już bez dekoracji z epoki.

15 http://www.perspectiv-online.org/pages/intro.php (11.03.2015). 


\section{Konserwacja i restauracja elementów wystaw scenicznych, czyli zestawów malarskich dekoracji teatralnych}

Tak jak w każdym innym przypadku, również w odniesieniu do kolekcji dekoracji teatralnych rolą zabiegów przeprowadzanych bezpośrednio na jej elementach jest zwiększenie szans przetrwania tego dziedzictwa. Efekty dokonanych zabiegów mogą w sposób istotny wpływać na wartości, których zachowanie, obok materii, jest celem wszelkich konserwatorskich przedsięwzięć. Przedstawienie zabiegów dotąd wykonanych pozwoli przyjrzeć się tym ostatnim zagadnieniom. Prezentując je, oparto się na publikowanych relacjach dotyczacych konserwacji-restauracji w kolekcjach dekoracji teatralnych, pojawiających się od lat $90 .{ }^{16}$, jak i na danych pozyskanych bezpo-

${ }^{16}$ V. Zemanová, H. Klouda, Restaurováni baroknich kulis aámeckébo divadla Céském Krumlové, [w:] Barokni divadlo na zamku v Ceském Krumlové, Sbornik prǐspevkè pro odborný seminár v Céském Krumlové, 27.0.- 30.9.1993, Praha-České Budèjovice 1993, s. 60; W. Kozak, Dekoracje teatralne z. Zamku w Łańcucie, „Biuletyn Informacyjny Konserwatorów Dzieł Sztuki” 1996, 7, nr 3-4 (26-27), s. 21; A.J. Rowe, op.cit., s. 648-653; S. Timm, op.cit., s. 114, 119; J. Ortner, Die Bühnenbilder des Barockteaters Stift : Lambach in Oberösterreich, Untersuchung, exemplarische Konservierung und Restaurierung, „Zeitschrift für Kunsttechnologie und Konservierung” 1999, 13, n. 2, s. 305-316; V. Trémoulet, Les décors du petit théâtre de Compiègne: examen et intervention de sauvetage, [w:] Actes du colloque international Théatres de cour, théâtres privés, Compiègne, Musée national du château, 18-19 octobre 1996, Paris 1998, s. 24-31; V. Trémoulet, L'intervention..., s. 115-122; J. Bláha, Dekorace zámeckého divadla [w:] Materiály k dejinam zámeckébo divadla v Litomyšli, red. Jiři Bláha, Litomyšl 2003, s. 20, 21; V. Trémoulet, Conservation et restauration des décors, [w:] Théâtre de Cour: Les spectacles à Fontainebleau au XVIIIe siècle, red. Vincent. Droguet, Marc-Henri Jordan, Paris, 2005, s. 85-89; V. Kern, op.cit., s. 34-46. Wcześniej pojawiały się relacje dotyczące nie kolekcji dekoracji, a kurtyn i panoram jako obiektów stanowiących odrębne dzieła malarskie: W. Blauensteiner, Die Restaurierungdes Zauberfloetenvorhangs im an der Wien Theater, „Österreichische Zeitschrift für Kunst und Denkmalpflege” 1965, 19, s. 5154; G. A. Berger, Conservation of a theatre curtain by Picasso, „Maltechnik-Restauro” 1977, 83, nr 1, s. 51-56; E. Pruscha-Velim, Zur Restaurierungdes Bühnenvorhanges im Wiener Raimundtheater, „Restauratorenblältter” 1992, 13, s. 133-135. Wyjątkową na ich tle jest dotycząca amerykańskiego zbioru kurtyn z Vermont: Ch. Hadsel, M. Pagan, Vermont painted theatre curtains and their community custodians, [w:] ICOM Committee triennial Meeting, The Hague 12-16 September 2005, London 2005, s. 904-910. Informacje dotyczące konserwacji kurtyn zebrat: D. Markowski, Obrazy wielkoformatowe na plótnie (panoramy, kurtyny teatralne) w procesie ich konserwacii, [w:] D. Markowski, S. Kamiński, M. Wachowiak, Wybrane zagadnienia konserwacji i re- 
średnio w miejscach ich przechowywania, z dokumentacji i zapisków oraz w wywiadzie $z$ opiekunami zbiorów i konserwatorami ${ }^{17}$.

Przedstawione poniżej informacje dotyczą zabiegów konserwatorskich i restauratorskich wykonanych na elementach zestawów malarskich dekoracji scenicznych pochodzących najczęściej ze zbiorów teatrów prywatnych, gdyż w takich przede wszystkim miały szansę się zachować do dzisiejszych czasów. Przeanalizowane zostały dane dotyczące jedynych tego typu zbiorów zachowanych w Polsce, z zamku w Lańcucie, dwu dworskich czeskich teatrów Českiego Krumlova i Litomyšla, trzech dworskich niemieckich z Ludwigsburga, Gotha, Meiningen, francuskich z teatru Marii Antoniny w Wersalu „małego teatru” (Ludwika-Filipa) w Compiègne i dawnego teatru Napoleona III w Fontainebleau. Pozostałe pochodziły klasz-

stauracji sztuki nowoczesnej, Torú 2010, s. 233-256. Zagadnienia dotyczące samych kurtyn zasadniczo wyłączono z niniejszego opracowania.

17 Informacje nie opatrzone przypisami bibliograficznymi zostały uzyskane na miejscu, tj. w miejscach przechowywania kolekcji dekoracji scenicznych od pracowników, z udostępnionej dokumentacji lub bezpośrednio od wykonawców prac. Odpowiednio: część danych dotyczacych konserwacji przeprowadzonych w latach 1961-1970 w Českim Krumlovie i dane dotyczące konserwacji zestawu Gabinet w Litomyšlu w 2003 - Jiři Bláha; notatka dotycząca konserwacji kulis i przezroczy w Českim Krumlovie autorzy Véra Zemanová, Hynek Klouda [mps, bez tytułu], 1982, Státni Hrad à Zámek Český Krumlov; dane o konserwacji elementów na krosnach i sufitów w latach 2003-2004 Českim Krumlovie - bezpośrednio od wykonawców Miroslava Križka, Pavla Padevět; dane o konserwacji z lat 1987-1995 w Ludwigsburgu - wg bezpośredniej relacji Saskii Esser i Felixa Muhle z Vermögen und Bau Baden-Württemberg Amt Ludwigsburg Schlossverwaltung; dane dotyczące konserwacji dekoracji z Meiningen z lat 1995-1999 i kontynuacji - informacje z dokumentacji konserwatorskiej pracowni konserwatorskiej AKR Pracher w Würzburgu, przekazane w Theater Museum, Kulturstiffung Meininger-Eisenach; Meininger Museen przez Volkera Kerna; część niepublikowanych informacji o pracach konserwatorskich w Compiègne - z dokumentacji: Valérie Trémoulet, Décors scéniques du Petit Téâtre Louis-Philippe du château de Compiègne, intervention de conservation 9 juillet- 3 aôut 1996, [kps], 1996,CPPA, Gaillac; dane o pracach przeprowadzonych w latach 1980-tych w Kortrijk z raportu (bez nazwy) z Vlaamse Technish Instituut (VTI) Gilberta Vnacker i Etienne Maton, udostępnionego przez dr Bruno Froment, kolejne z lat 2011-2013 z relacji ustnej Griet Blanckaert z Artesis Hogeschool K.A.S.K. w Antwerpii; informacje dotyczące prac przeprowadzonych w Łańcucie w 1995 roku z dokumentacji konserwatorskiej: Wojciech Kozak, Krzysztof Gargas, Teresa Pieniążek, „Konserwacja dekoracji teatralnych”, [kps], Jarosław 1995, oraz uzyskane bezpośrednio od kierującego zespołem Wojciecha Kozaka. 
tornego teatru w Lambach w Austrii. i z teatru miejskiego - w Kortrijk/ /Courtrai) w Belgii ${ }^{18}$.

\section{Krótka charakterystyka wybranych zbiorów dekoracji scenicznych}

Zabiegom konserwatorskim i restauratorskim poddawano grupy elementów jednego typu, budujące sceniczne mystany, czyli wchodzące w skład kompletu dekoracji lub poszczególne komplety, rzadziej tylko pojedyncze elementy wymienionych kolekcji. W celu unaocznienia skali i rodzaju konserwatorskich przedsięwzięć poniżej przytoczono podstawowe dane dotyczące samych zbiorów, tj. czas powstania i typ obiektów, które się na nie składaja, ich liczebność i rozmiary, zasięg dotychczas przeprowadzonych zabiegów i czas ich wykonania ${ }^{19}$.

Malarskie dekoracje sceniczne zachowane w osiemnastowiecznym teatrze zamkowym marszałkowej Lubomirskiej w Lańcucie pochodzą z okresu już dwudziestowiecznej modernizacji tegoż, przeprowadzonej przez spadkobierców, Potockich, w latach 1911-1912. Namalowane w Wiedniu w tym czasie bądź nieco wcześniej, w nieokreślonej bliżej malarni, zapewne jednego z konsorcjów dekoratorskich, tworzyły scenerie repertuarowe $-S a$ -

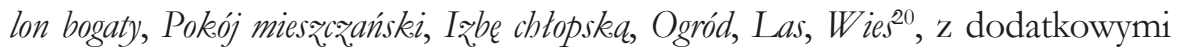
prospektami pozwalającymi tworzyć warianty, dwie dekoracje przedstawiajace zamkowe wnętrza przybyły w latach 1926-1927. Zachowane zbiory to łącznie ponad 140 elementów ${ }^{21}$, w sumie o powierzchni ok. $800 \mathrm{~m}^{2}$, mogących tworzyć, w różnych zestawieniach, osiem scenerii. Prospekty z tego

18 Prócz wymienionych badaniami objęto także kolekcje Drottningholm w Szwecji i Halden w Norwegii, oraz w Eu we Francji; nie przedstawiono ich poniżej, gdyż zabiegi stricte konserwatorskie i restauratorskie do 2013 roku ich nie dotyczyły.

19 Obszerniejsze informacje dotyczące kolekcji i pełną bibliografię zawiera rozprawa, E. Szmit-Naud, Kolekcie dekoracji..., s. 59-111, 256-283.

20 Archiwum Główne Akt Dawnych w Warszawie, Archiwum Potockich z Lańcuta, Rachunki t.s. budowy Sali teatralnej na zamku w Lańcucie, 1911: sygn.: PL_1_350_818_70; J. Sokołowska-Gwizdka, Ze wspomnień starego lokaja,'Polonia Kalifornijska", maj/czerwiec 2000, 5, s. 16.

21 Według rachuby autorki, dokonanej w 2009 roku, wynikającej z analizy udostępnionych kart powstałych w latach 1955-2003. 
zbioru mają szerokość maksymalnie $7 \mathrm{~m}$ przy wysokości od 4,2 do 4,7 m (il. 6). Konserwacji-restauracji przeprowadzonej w 1995 roku poddano cały zbiór dekoracji z wyłączeniem praktykabli.

Kolekcja Českiego Krumlova w zasadniczym zrębie zawiera zestawy dekoracji oryginalnie stworzone dla barokowego dworskiego teatru Schwarzenbergów przez wiedeńczyków Hansa Wetschela i Leo Märkla w 1776 roku oraz części zestawów, głównie kulisy, pochodzące dworskich teatrów, przede wszystkim z innych posiadłości właścicieli Krumlova. Główny zrąb kolekcji to krumlowskie zestawy składające się na: Las, Ogród, Plac public そny (in. Ulica lub Miasto), Port, Obóz wojskony z wariantem w postaci Obleżonego miasta, Urocsysta sale (barokowa), z wariantem z innym prospektem dającym uystawe Światyni, Więrienie, Pokój mieszczaniski i Gabinet oraz kurtyna ${ }^{22}$. W sumie to ok. 350 elementów, z czego 191 należy do wymienionych kompletów. Rozmiary prospektów w krumlowskiej kolekcji mieszczą się w granicach 7 do 7,5 m szerokości i 5,35 m do 6 m wysokości. Kulisy boczne głównej kolekcji mierza powyżej $4 \mathrm{~m}$ do $7 \mathrm{~m}$, przy czym szerokość najszerszych przekracza nieznacznie $2 \mathrm{~m}$. Kulisy dodatkowego zbioru są niższe, maja nieco poniżej i powyżej $3 \mathrm{~m}$ i są węższe. Od 1961 r. do lat 70. XX wieku konserwacji-restauracji poddano prospekty $\mathrm{z}$ wyjątkiem jednego i nieokreślone bliżej całe zestawy, następnie w latach 80. do 1993 r. konserwowane były kulisy kolejnych scenerii i elementy zawierające przęrocza (tj. wykorzystujace efekt prześwitywania przy oświetleniu od tyłu), a od 1992 do 1994 r. i w od 2. poł. lat 90. do 2000 roku oraz w latach 2003-2004 poddano zabiegom elementy zbudowane na krosnach, w tym ponownie ferm Červeny Dvưr, o skomplikowanej konstrukcji oraz elementy zwieszane - sufity.

Dekoracje sceniczne zamkowego teatru hrabiego Wartemberga w Litomyšlu zostały stworzone w 1797 roku przez najbardziej znanego malarza-dekoratora habsburskiego cesarstwa epoki, pracującego dla dworu wiedeńskiego i wielu teatrów publicznych i prywatnych Wiednia, Josepha

22 Na podstawie: wewnętrznego dokumentu Muzeum w Zamku Českim Krumlovie: Základni evidence fondu zameckého divadla- leden 2001, Dekorace I; K. Cichrová, Soupis dekoraci a kostýmu zámeckého divadla v Céskem Krumlové (podle inventáre hradu a zamku Ceské) Krumlov), [w:] Barokni divadlo na zámku v Ceském Krumlové, Sbornik prisspèvki pro odborný seminar v Ceském Krumlově 27.9.-30.9.1995, Praha-České Budějovice 1995, s. 73, 74. 
Platzera. Jest to jedyny zachowany zbiór malarskich realizacji jego scenicznych projektów. Litomyska kolekcja, prócz elementów stałych (trwale związanych ze scena - dwu kurtyn i płaszrza Arlekina), obejmuje szesnaście zestawów dekoracji, nie zawsze kompletnych, z których można było zestawić dwadzieścia wariantów i dwa zestawy nieprzypisane Platzerowi. Scenerie to Sala gotycka, Sala nowos̀ytna (in. Kolumnowa albo Ceremonialna), Wiezienie w dwóch wariantach, Pokój mieszczański, Gabinet, Kawiarnia, Pokój ministra, Kościót (in. Przedsionek kościoła), Wnetrze wiejskie (iz̧ba chtopska), Warsztat zbrojownika, Las, Pejzaż wiejski, Ogród francuski, dwa widoki Ulicy i Scene na plaży (Morze) oraz Jaskinie i dwie dekoracje Salon niebieski i Salon źótty prawdopodobnie autorstwa lokalnego malarza Dvořáka i elementy, głównie kulisy dodane później ${ }^{23}$. Łącznie to ponad 200 elementów, w tym 98 praystawek, terenów, fermów oraz innych akcesoryjnych części dekoracji ustawianych wolno. Największe obiekty z kolekcji mają od 3,45 do 4 m wysokości, prospekty $-4 \mathrm{~m}$ (il. 7). Pierwsze zabiegi konserwatorsko-restauratorskie wykonano w 1956 r., kolejne w latach 1967-1972. Dotyczyły one dwóch kurtyn, trzynastu prospektón i jednego kompletu kulis. Następnie w 1992 r. konserwacji poddano jeden prospekt, a od roku 2003 do chwili obecnej ponownie pięć spośród tych konserwowanych 40 lat wcześniej, a w przypadku zestawu $G a$ binet także jego pozostałe elementy oraz część innych obiektów kolekcji.

W teatrze dworskim w pałacu w Ludwigsburgu w Wirtembergii, powstałym z inicjatywy księcia Carla Eugena w 1758-1759 roku, zgromadzono zachowane dekoracje tego i innych mniejszych dworskich teatrów wirtemberskich. Kolekcja traktowana jako całość reprezentuje przede wszystkim epokę klasycyzmu i składają się na nią elementy typowych dekoracji kompletowych w czternastu zasadniczych zestawach, z których, dzięki wariantom kulis, można skomponować szesnaście, obecnie niecałkowicie kompletnych, składających się z prospektu i czterech do sześciu par kulis. Sa to scenerie przedstawiające Pola Elizejskie (najstarsza), Pejzaż leśny z dwoma różnymi kompletami kulis, Pejzaż z winnicami, również z dwoma kompletami kulis, Pokój zamkony szary, Wnetrze rustykalne inaczej Izba chtopska

23 Jiři Hilmera, From the baroque to the Romantic/ Du baroque au romantisme, „Czech theatre", 1994, nr 7, s. 63-72; Jiři Bláha, Dekorace zámeckébo divadla, [w:] Materiály ke dejinam...., s. 18-33. 
z w połowie zachowanym prospektem, Więienie i fragmenty zestawów Krużganek gotycki, Kościót, Sala berbowa z dekoracja neogotycką i Ulicy z kulisami powstałymi w różnym czasie. Te scenerie powstały prawdopodobnie w czasach Fryderyka II, tj. po 1797 do początku XIX wieku². Lącznie kolekcja zawiera 2 kurtyny, 14 prospektów i 139 kulis i wspomnianych innych elementów scenerii (z wyłączeniem niezachowanych sufitón). Najniższy z prospektów mierzy 6,36 m wysokości, najwyższy $9,87 \mathrm{~m}$ przy szerokości od 6,86 $\mathrm{m}$ do 10,34 m. Wysokości kulis zależnie od usytuowania na scenie kształtuje się od 4,10 m do 6,36 m wysokości i 1,08 do 1,65 m szerokości. W latach 1987-1995 konserwacji-restauracji poddano wszystkie prospekty oraz kulisy znajdujące się w kolekcji wyłączywszy dwie.

Kolekcja teatru zamku Friedenstein w Gotha w Turyngii w swych poczatkach sięgających XVII wieku, w obecnym kształcie z 3 ćw. XVIII wieku jest znacznie skromniejsza. Składa się na nią kurtyna, dwa fragmenty dekoracji łuku proscenium z 1785 r. i jedna kulisa z 1775 r. ${ }^{25}$, oraz kulisy $i$ inne elementy scenerii przedstawiających wnętrza, najprawdopodobniej już XIX-wieczne, niekompletne: Pokoju drennianego (Holzzimmer), Pokoju Skórzanego (Lederzimmer), Pokoju blekitnego (Blauerzimmer) najprawdopodobniej XIX-wieczne, niestanowiące dziś pełnych kompletów. Prócz tego części będące najprawdopodobniej bocznymi częściami (tzw. draperiami) płaszcza Arlekina, namalowane na płótnie odzyskanym z wcześniejszej dekoracji, dwa fermy i przystawka, i jeden niewielki element na krośnie trudny do zidentyfikowania. W sumie to 33 elementy zgromadzone w magazynie, 4 na wystawie i kurtyna - zamontowana w teatrze. Do tej pory tylko kurtyna i elementy eksponowane na wystawie zostały poddane konserwacji-restauracji, w roku 1997 i następnych.

Zachowana w Meiningen, obecnie w budynku zamkowej Ujeżdżalni, kolekcja dekoracji scenicznych zawdzięcza swe powstanie, w dosłownym znaczeniu, księciu Sachsen-Gotha Jerzemu II, który realizację swych

24 S. Esser, Bühnenschatze vom Dachboden, Die historischen Theaterdekorationen [w:] Das Ludwigsburg Schlosstheater, Kultur un Geschichte eines Hoftheatres, Herausgegeben von des Ludwigsburger Schlossfestspielen, Ludwigsburg 1998, s. 43-58.

${ }_{25} \mathrm{Na}$ podstawie informacji uzyskanych bezpośrednio od kustosza zbiorów, Elisabeth Dobritzsch. 
scenicznych koncepcji powierzal przede wszystkim Maxowi i Gottholdowi Brücknerom z Coburga. Pojedyncze prace wykonał inny dekorator z Coburga, Friedrich Lütkemeyer, kilka stworzyło dekoratorskie konsorcjum Jana Kautsky'ego w Wiedniu czy Moritza Lehmanna albo Angela lub Simona Quaglio z Monachium. Była to oprawa sceniczna konkretnych sztuk, do każdej po kilka kompletów złożonych z kilku planów, głównie do dzieł Szekspira, ale także i innych, już XIX-wiecznych twórców m.in. Kleista czy Schillera. Malowidła powstały na przestrzeni funkcjonowania teatru księcia Jerzego w latach 1866-1914. Są to wyłącznie elementy zwieszane, bez sztywnych konstrukcji, choć tworzące zestawy zbudowane zgodnie z zasadami kulisowej dekoracji, składające się z prospektów, sufitón, wielu przecię́ i wiszących kulis, praysstawek. Obecnie kolekcja liczy 275 elementów. Jest 10 kompletnych zestawów, w tym na przykład dwa do Kasi z Heilbroonu, to jest łącznie 36 elementów (il. 8.). W przypadku pozostałych scenerii zachowały się tylko po trzy, cztery elementy. Rozmiary elementów kolekcji są pokaźne, prospekty osiagają od $12 \mathrm{~m}$ do $15 \mathrm{~m}$ szerokości i $6,3 \mathrm{~m}$ do 7,2 m wysokości. Kulisy w formie przeciéć (jak kulisy boczne połączone sufitem) maja podobne wymiary - od 11,75 m do 14,8 m szerokości i 7,2 $\mathrm{m}$ do 7,7 m wysokości. Zestawy dekoracji są sukcesywnie poddawane konserwacji-restauracji. W latach 1979-1985 poddano zabiegom części zestawów Obóz pod Pilznem i Zaczarowany las oraz prospekty do Kupca weneckiego i Wilhelma Tella, a od 1995 do 2008 roku 29 kolejnych różnych elementów kolekcji, prospek.ty, kulisy, luźne elementy zestawów, m.in. Wilhelma Tella, Zimowej opowieści, Kasi z. Heilbrronn ${ }^{26}$, prace są kontynuowane.

W prywatnym teatrze dworskim zbudowanym w 1779 r. w Wersalu dla Marii-Antoniny zwanym Petit Théâtre de la Reine lub Théâtre du Petit Trianon mieści się niewielka kolekcja dekoracji, wprawdzie nie z czasów jego założycielki, ale zawierająca najstarszą zachowaną we Francji dekorację sceniczną królewskich pracowni Menus Plaisirs Światynia Minemy (Temple de Minerve) z 1754 r. według projektu dwu spośród słynnych braci

26 Opracowano opierając się na informacjach zawartych w: V. Kern, Das meininger Hoftheater, Regensburg 2004; Meiningen Zauberwelt der Kulisse, Lasst uns ein Zeichen setzen..., red. M. Keller, Meiningen 1999, s. 34-46 oraz bezpośrednio uzyskanych od autora. 
Slodtz, Sébastien-Antoine et Paul-Ambroise ${ }^{27}$, namalowaną dla dworskiego teatru w Fontainebleau oraz teren z 1787 roku. Pozostałe elementy pochodzą z lat 1834-1838 i zostały specjalnie zamówione przez króla Ludwika-Filipa u słynnego malarza-dekoratora Pierre'a-Luca Charles'a Ciceriego ${ }^{28}$. Sa to prócz dwu kurtyn (głównej i antraktowej) oraz płaszcza Arlekina zestawy Las, Izba wiejska, Plac publičny, Salon zamkniety, nie w pełni kompletne. Kolekcja dziś składa się z 85 do 90 elementów ${ }^{29}$, w tym 60 kulis. Najniższe kulisy maja niewiele ponad $4 \mathrm{~m}$, pozostałe 5,5-6 m i szerokość od 1,2 do $2 \mathrm{~m}$, tereny są niskie - 0, 2 i 0,9 m, przy długości 2,9 i 4,5 m, prospekty mierza 6,5 na 9,23 m i 6,97 na $9,34 \mathrm{~m}^{30}$. Obiekty kolekcji poddano wstępnym zabiegom zabezpieczającym w 2001 r., kontynuowanym w roku 2006, w 2011 wykonano konserwację-restaurację zestawów Las i Iz̧ba chtopska.

W zamku Compiègne, w teatrze utworzonym dla króla Ludwika-Filipa w 1832 roku, tzw. Petit théatre $e^{31}$, znajduje się kolekcja malarskich dekoracji scenicznych złożona w głównej mierze z zestawów repertuarowych mystaw zamówionych specjalnie dla tego teatru. I w tym wypadku, jak w poprzednim, ich twórca był Pierre-Luc Charles Ciceri. W latach 1833, 1834 i 1836 - Salon bogaty zamkniety, Pałac bogaty, Salon Moliera z ,,adamaszkowa niebieska tapeta", Pokój wiejski, Wiezienie, Las, Plac publiczny [miejski], Pałac gotycki, Salon mieszrzański, Pokój ubogi zamkniety, Grota, oraz Osada i uzupełniające przystawki. Pozostałe elementy kolekcji to Mały salon z „tapeta zielona w romby i kwiaty”, część wypożyczonych już za czasów Drugiego Cesarstwa, w 1863 roku: Salonu w stylu renesansowym, Ludwika XV, Ludwika XVI, Ubogiego pokoju i Wsi, oraz elementy dekoracji powstałych w XIX wieku dla innych królewskich teatrów, już nieistnie-

27 Szkice tej dekoracji zachowały się w Bibliotece Opery w Paryżu: D. Lauvernier, op.cit., s. $130-133$.

28 J.-P. Gousset, D. Richter, Les décors de scène conservés au théatre de la Reine et à l'Opéra royal de Versailles, „Versalia”, 6, 2003, s. 19-23.

29 W przeglądzie dokonanym w 2006 r. stwierdzono obecność 85 elementów. Spis wykonany przez instytucję w 2011 r. wykazał 90 sztuk dekoracji, zapewne łącznie z nowo dodanymi kopiami.

30 Przegląd i pomiary wykonane na miejscu w $2006 \mathrm{r}$.

31 Dla odróżnienia od drugiego dworskiego teatru w zamku, Théâtre Imperial, zbudowanego dla Napoleona III. 
jących $^{32}$. Lącznie kolekcja dekoracji scenicznych zgromadzonych w teatrze Ludwika-Filipa w Compiègne liczy 392 elementy, z czego 314 wykonanych zostało do tego teatru, jak można sądzić na podstawie ich rozmiarów. Wysokość przykładowych kulis sięga od $4 \mathrm{~m}$ do $5 \mathrm{~m}$ przy szerokości od 1,6 m do 3,3 m, praystawki-akcesoria mogą osiagać do $2 \mathrm{~m}$ wysokości i 3,5 m szerokości; duży ferm ma 7,4 m szerokości na 2,8 mmm wysokości, przykładowy prospekt, mierzy $8 \mathrm{~m}$ na $6,8 \mathrm{~m}$. Prace podjęte podczas kampanii przeprowadzonej w 1996 r. polegały na zabiegach konserwatorskich i objęły 314 elementów zbioru, w roku 2006-2007 jeden element - duża przystawka Buisson fleuri (Kwitnacy krzew), P.L-C. Ciceriego została poddana konserwacji-restauracji w ramach pracy dyplomowej.

W teatrze powstałym w latach 1853-1856 na zlecenie Napoleona III w zamku Fontainebleau mieści się kolekcja złożona z elementów zestawów dekoracji z lat 1760-1780 zbudowanych na krosnach (fermów, praystawek, terenów) w liczbie 46 oraz ośmiu prawie kompletnych XIX-wiecznych zestawów składających się na: Las, Pałac mauretański, Pałac gotycki, Salon bogaty, Wnetrze wiejskie i, prawdopodobnie, Plac publiczny, Pałac Empirowy. Pochodzenie tych obiektów jest różne. Starsze obiekty kolekcji moga pochodzić z poprzedniego teatru dworskiego w Fontainebleau. Jako oprawa sceniczna konkretnych przedstawień, co można stwierdzić dzięki inskrypcjom na odwrociach, zostały stworzone w pracowniach Menus Plaisirs du Roi, m.in. według projektów Pierre'a-Adriena Paris'a, Michela-Ange Challe’a, Michela-Ange Slodtza, namalowane m.in. przez Pierre'a Sagereta i malarza Mazière ${ }^{33}$. Późniejsze zestawy powstały dla sali teatralnej aranżowanej w prywatnej rezydencji króla Ludwika-Filipa, zamku w Eu - m.in. Pałac gotycki, kilka zostało stworzonych dla teatru Marie-Antoinette w Wersalu. Według niedawno dokonanego spisu kolekcja liczy 250 elementów dekora-

32 J. Kuhnmunch, Les décors de scène du petit théatre de Compiègne; aperçu historique, [w:] Actes du colloque..., s. 19-23.

33 A. Lefébure, La salle de spectacle du château de Fontainebleau: la restauration du mobilier et des décors de scène, [w:] Actes du colloque ..., s. 57-61; M.-H. Jordan, Eighteenth-century scenery at Fontainebleau, [w: The World of Baroque Theatre, A Compilation of Essays from the Cesky Krumlov conferences 2004, 2005 and 2006, Český Krumlov, 2007, s. 43-52; idem, Décors et mises en scène d'un théâtre de la Cour, [w:] Théâtre de Cour..., s. 73-84. 
cji ${ }^{34}$. Starsza, XVIII-wieczna część kolekcji, tj. 46 elementów na krosnach, została poddana konserwacji-restauracji kilka lat po jej odkryciu w 2000 r., w związku z zorganizowaną wystawą $a^{35}$; zabiegom poddano wówczas także dekorację Pałacu Mauretańskiego, osadzonego na scenie (il. 9).

Zbiór malarskich iluzjonistycznych dekoracji scenicznych w teatrze opactwa benedyktyńskiego w Lambach w Austrii pochodzi z 3 ćw. XVIII i XIX w. Teatr klasztorny okres rozkwitu przeżywał w późnym baroku, za czasów opata Amandusa Schickmayra. Odnowienia istniejącego od średniowiecza teatru dokonał klasztorny malarz Johann Wenzel Turetschek w 1769 r., przed odwiedzinami Marii Antoniny w drodze do Paryża (1770). Przypuszczalnie był też wykonawcą dekoracji scenicznych. Malowidła te to, prócz kurtyny, trzynaście typowych scenerii złożonych z prospektóm, kulis i sufitón: Las, Miasto, Światynia, Czernona Fasada, Pejzaż egzotyczny, Park, różne wnętrza: Pokój klasycystyczny, Sala rycerska, Sala myśliwskea, Pokój Biedermeier, Iz̧ba chtopska (in. Kuchnia), Więzienie, jedno inne wnętrze, łącznie jest to 39 kulis i 12 prospektów, w tym dwa malowane dwustronnie. Prospekty osiagaja rozmiary od 2,88 $\mathrm{m}$ do 3,9 $\mathrm{m}$ wysokości przy 4,4 $\mathrm{m}$ do $6,32 \mathrm{~m}$ szerokości. Krosna kulis mierzą 304-310 cm wysokości i 100-113 cm szerokości. Konserwacji-restauracji jednej z kulis, mającej stanowić wzorzec i wyznaczającej program prac przy następnych dokonano w 1998 r. $^{36}$

W teatrze miejskim w Kortrijk (Courtrai) w Belgii mieści się zbiór dekoracji scenicznych zbudowany jeszcze zgodnie z zasadami sceny włoskiej choć już w latach XX wieku. Sa to w większości scenerie wykonane przez znanego malarza dekoratora, Alberta Dubosq pracującego w Brukseli, wykształconego w Paryżu, dla tego właśnie teatru. Dwie serie, pierwsza z 1914, zawierająca trzynaście kompletów i druga, z 1922-1923, jedenaście zestawów i dodatkowe warianty prospektón oraz zakupiona okazyjnie sceneria namalowana w 1913 przez Dubosq dla Tournai, to dekoracje repertuarowe, jak i wykonane do konkretnych spektakli operowych, które mogły

34 Rapport d'activité de l'Etablissement public du musée et du domaine national de Versailles, Versailles, 2010, s. 83.

35 Théâtre de Cour - Les spectacles à Fontainebleau au XVIII ${ }^{\mathrm{e}}$ siècle.

36 J. Ortner, op.cit. Opisane rezultaty pracy dyplomowej wykonanej w Institut für Konservierung-Restaurierung Akademie der bildenden Künste we Wiedniu, w 1998. 
być też wykorzystywane w innych. Na zbiory składają się Salony w stylu Ludwika XV i Ludwika XVI, Salon mieszcranski, Wnetrze wiejskie, Pałac gotycki, Wiezienie/zamek/krypta, Duże wnetrze w rodzaju Sali, które pozwalało przekształcić teatr w salę balowa, kilka „placów publicznych” średniowieczny, wspótcresny, hispano-wtosko-arabski (do Carmen i Cyrulika sewrilskiego), egzotyczny (indyjski), Światynia egipska z krypta (do Aidy), Widok zewnetrzny egipski, Pałac egipski, Kościót, oraz pejzaże Las, Park/ogród, Pejzaż, skalisty, Morze oraz Miasteczleo z kościotem, Las åjatycki i dodatkowe prospekty i fermy, do łączenia $\mathrm{z}$ wymienionymi oraz komplet z Tournai - Pałac raymsko-bizantyjski. Wymienione zestawy nie są dziś w pełni kompletne, inwentaryzacja i identyfikacja są w toku, elementy kolekcji określa się obecnie na co najmniej 353 sztuki $^{37}$, ich łączna powierzchnię oszacowano w 1985 r. na około $3000 \mathrm{~m}^{2}$. Sa to obiekty o dużych rozmiarach, największy prospekt ma $10 \mathrm{~m}$ wysokości przy $14 \mathrm{~m}$ szerokości, inny $8 \mathrm{~m}$ wysokości na $10 \mathrm{~m}$ szerokości, szerokość pozostałych i fryzóm jest zróżnicowana - od 4,4 m do $14 \mathrm{~m}$. Wysokość przykładowych kulis to $6 \mathrm{~m}-6,4 \mathrm{~m}$, szerokość $1,5-1,7 \mathrm{~m}$ (il. 10), w przypadku zbudowanych z kerosien lamanych - 2,6-2,8 m.

\section{Przeprowadzone zabiegi konserwatorskie i restauratorskie}

Stan dekoracji teatralnych w kolekcjach będących przedmiotem opracowania sprawiał, że wśród zabiegów najbardziej koniecznych, prócz oczyszczenia, były przede wszystkim konsolidacja i naprawy oraz wzmacnianie płóciennego podłoża i naprawy konstrukcyjnych elementów nośnych. Uzupełnienia warstw leżących na płótnie miały różny zakres i nie zawsze były podejmowane.

Pionierami w dziedzinie konserwacji-restauracji zbiorów dekoracji teatralnych byli konserwatorzy czescy. Najwcześniejsze pojedyncze zabiegi niemające charakteru doraźnych napraw dokonywanych przez malarzy czy maszynistów, a przeprowadzane przez konserwatorów wykonane zostały już w końcu lat 50. w litomyskich zbiorach, ale zasadniczo w latach

\footnotetext{
37 Według opisu z 1985 r. i ostatnich danych, z 2013 r., udostępnionych przez dr. Bruna Formenta.
} 
60.-70. w obu kolekcjach czeskich, tj. litomyskiej i z Českiego Krumlo$\mathrm{va}^{38}$. Już w roku 1956 rozpoczęto konserwację-restaurację elementów kolekcji, co w skali europejskiej było pierwszym przedsięwzięciem tego rodzaju. $\mathrm{Z}$ kolei barokowe dekoracje sceniczne w teatrze rodu Schwarzenbergów (z 1765-1766) w Českim Krumlovie, ocalałe wraz z teatrem, już po wojnie w ciagu kilku lat podlegały przyspieszonej degradacji, choć nie wskutek bezpośredniego ich użytkowania, po czym dalsze pogorszenie stanu przyniosła intensywna eksploatacja teatru wraz z jego zabytkowym wyposażeniem od 1958 roku przez 8 lat w ramach Festiwali Czech Południowych ${ }^{39}$, pierwsze prace konserwatorskie podjęto w $1961 \mathrm{r}$. Informacje z tamtego okresu są zdawkowe. Późniejsze wnoszą już więcej szczegółów, choć część relacji, także tych z ostatnich czasów, jest pozbawiona technicznych danych, co do stosowanych środków. Z racji tego, że zaawansowanie degradacji obiektów poszczególnych kolekcji nie było identyczne, oraz faktu, że część z przeprowadzanych dotąd interwencji miała charakter wyłącznie ratunkowy i musiała być przeprowadzana w krótkim czasie, przytoczonych poniżej informacji o metodach i środkach nie można traktować porównawczo, jako wyrazu zawodowych preferencji różnych „szkół” konserwatorskich w danym okresie. Mimo wzmiankowanych ograniczeń sumaryczny przegląd przeprowadzanych zabiegów pozwala dokonać interesujących obserwacji, na podstawie których zarysować można ewolucję spojrzenia specjalistów-konserwatorów na zagadnienia konserwacji-restauracji tej grupy obiektów wymykających się kategoryzacji tradycyjnie stosowanej w odniesieniu do dzieł malarstwa.

Bazując na zebranych informacjach, trudno ustalić pogląd na temat jednego z podstawowych zabiegów, jakim w przypadku kolekcji dekoracji teatralnych jest ich dezynfekcja. Do lat 90. brak szczegółowych danych w tym zakresie. W dwóch przypadkach w latach 90. (Ludwigsburg,

\footnotetext{
38 Już w latach 50. zestawy litomyskich dekoracji teatralnych z końca XVIII wieku zostały fachowo opisane i udokumentowane fotograficznie w widoku ogólnym na scenie - J. Hilmera, Zámecke divadlo v Litomyšli, „Zprávy památkové péče” 1957, 7, nr 3-4, s. $113-138$.

39 Dane dotyczące powojennych losów teatru w Českim Krumlove i jego dekoracji zaczerpnięto z: V. Grisa, P. Jerie, K obnově quámeckébo divadla v Českem Krumlové, „Zpravy Pamatkove Peče" 2000, 60, nr 3, p. 87-94.
} 
Compiègne) poprzestano na wykorzystaniu denaturującego (białka drobnoustrojów) działania rozpuszczalnika - etanolu - stosowanego w kolejnych zabiegach lub napylonego na powierzchnię specjalnie w tym celu. Podczas zabiegów przeprowadzonych na jednym tylko elemencie dekoracji, konserwowanym w ramach pracy dyplomowej w ostatnich latach (fragment dekoracji z Compiègne, 2006-2007) ${ }^{40}$, przeprowadzono zabieg dezynfekcji ortofenylofenolem (Preventol). Można przypuszczać, że w przypadkach pozostałych interwencji, tak jak w trakcie kampanii konserwacji części kolekcji z Fontainebleau w latach 2002-2004, za wystarczające uznano mechaniczne usunięcie kolonii mikroorganizmów z obiektów podczas zabiegu oczyszczania ${ }^{41}$. W innym przypadku, konserwacji jednego z zestawów w Litomyšlu dezynfekcji poddano jedynie drewniane elementy konstrukcji.

$\mathrm{Na}$ temat oczyszczania powierzchni dekoracji teatralnych podczas prac konserwatorskich przeprowadzanych do lat 80 . brak wzmianek. Z dalszych informacji wynika, że w najbardziej podstawowej wersji wykonywano ten zabieg najczęściej mechanicznie, na sucho, pędzlami i z użyciem odkurzacza. Do oczyszczania odwrocia stosowano gąbki i gumki. Miękkimi gumkami czyszczono też lico. W przypadku dekoracji z Meiningen, przytrzymując malowidła na stole niskociśnieniowym, czyszczono warstwy malarskie pó1suchym pędzlem. Zabrudzenia trwale wklejone w warstwę malarską, plamy i zacieki niwelowano przy użyciu rozpuszczalników organicznych - olejku terpentynowego, toluenu oraz wody, z dodatkiem wody utlenionej (w Českim Krumlovie, podczas ostatniej kampanii konserwatorskiej, 2. poł. lat 90. do 2004), podczas restauracji kurtyny przeprowadzanej w Gotha w 1997 r. ${ }^{42}$, problem silnych zabrudzeń starano się rozwiązać, stosując wilgotne kompresy i tepowanie. Podczas konserwacji-restauracji dekoracji

40 C. Bringuier, „Le buisson fleuri du théâtre Louis-Philippe au château de Compiegne: étude et restauration d'un élément de décor scénique du XIXe siecle. Recherche d'un nouveau renfort, memoire de fin d'etudes", [kps] INP, Paris 2007, s. 112-124, 129-130 (wersja pdf udostępniona przez bibliotekę INP).

${ }^{41}$ V. Trémoulet, Conservation et restauration..., s. 89.

42 Przykład kurtyny konserwowanej w Gotha przywołano, gdyż autorką prac konserwatorskich, dotyczących kurtyny, oraz wykonanych następnie, niezrelacjonowanych w literaturze, dotyczących elementów dekoracji teatralnych eksponowanych w Gotha, jest ta sama osoba i jest prawdopodobne, że wykonane zostały z zastosowaniem tych samych metod. 
z Ludwigsburga, w latach 1987-1995 zabrudzenia usuwano, przeprowadzając przepłukiwanie etanolem odsysanym na stole próżniowym. W Lambach, gdzie przeprowadzono przykładową konserwację kulisy (1999) ${ }^{43}$, do usuwania przebarwień używano wody - zwilżonych woda gąbek, pary wodnej, zmiękczano i usuwano mechanicznie. U obrębie zacieków oczyszczanie przeprowadzano na stole niskociśnieniowym, napylając wodę aerografem i odsysając.

Drewniane konstrukcje nośne, niezależnie od czasu dokonywania interwencji, zarówno w elementach zwieszanych, jak i sztywnych, najczęściej poddawane były reperacjom stolarskim, co oznaczało wymianę zniszczonych fragmentów, a nawet całości na nowe. Czasem łączono te zabiegi z impregnacją fragmentów uszkodzonych przez owady, które zdecydowano zachować, bądź, w przypadku kampanii o wyłącznie ratunkowym charakterze (Compiègne, 1996) - z dezynsekcją cypermetryna. W Českim Krumlovie w latach 70. profilaktycznie przesycano wstawki z nowego drewna środkami chroniącymi przed atakiem szkodników. Dezynsekcji drewnianych konstrukcji w zestawie dekoracji konserwowanym w 2003 roku w Litomyšlu dokonano w podobny sposób. W początkowym okresie prace przy konstrukcjach nośnych mieściły w sobie usuwanie elementów takich jak uszka, haki, sznury itp. - wszelkich „niezrozumiałych” i „przeszkadzających”, jeśli za punkt odniesienia przyjąć budowę dzieł malarstwa sztalugowego. Symptomatyczne jest także, że do lat 80. (Český Krumlov), dokonując wymiany krosien, w konstrukcji nowych stosowano uproszczenia skutkujące np. zmianą charakteru elementów zawierających przęrocza, czyli fragmenty półprzejrzyste, oświetlane od tyłu w celu osiagnięcia specjalnych efektów iluzji - w fermie przedstawiającym Czerwony dwór ${ }^{4}$. W latach 70. stosowano też metalowe osłony krawędzi krosien, element obcy w konstrukcjach dekoracji teatralnych ${ }^{45}$. Podobnie postapiono przy konserwacji kulisy w Lambach, osłaniając krawędzie profilem aluminiowym. W narożnikach dodano meta-

43 Zamieszczone informacje i kolejne dotyczące konserwacji - J. Ortner, op.cit., s. 313-315 .

44 J. Bláha, Conservation, restoration and storage of old stage sets in Czech Republic, [kps], 10 X 2007, s. 10, 11 (archiwum autora).

45 Ibidem, s. 4. 
lowe kątowniki, a na górną krawędź nałożono osłonę z plexiglasu. Także w latach 90., podczas konserwacji-restauracji dekoracji z Lańcuta i Meiningen, w celu usprawnienia prezentacji czy przechowywania dokonywano wymiany sztang, czyli dragów stanowiących część konstrukcyjną elementów zwieszanych, nie zachowując oryginalnego systemu mocowań. W Łańcucie $\mathrm{w}$ trakcie konserwacji-restauracji usunięto górne i dolne sztangi, a górną krawędź płótna podklejono obustronnie tkanina, tworząc tunel, w który wsunięto aluminiowe płaskowniki trwale przymocowane następnie do rur z PCV. W przypadku dekoracji z Meiningen drewniane sztangi wymieniono na listwy aluminiowe ${ }^{46}$. Złamane sztangi w Gotha łączono szynami metalowymi. Planując prace przy strukturach nośnych elementów dekoracji z Lańcuta, zamierzano wymienić sztywne krosna na krosna z klinami, jednakże w toku prac nie dokonano tej zmiany.

Podczas zabiegów przeprowadzanych w późniejszym czasie w innych kolekcjach pozostano przy rozwiązaniach tradycyjnych, dokonując rekonstrukcji w drewnie zniszczonych elementów. Podczas kolejnej interwencji dokonanej na wspomnianym fermie Czerwonego dworu, w Českim Krumlovie w 2007 roku, przywrócono dawną konstrukcję krosien z uchwytami na biskwity (lampki-świeczki) i tym samym funkcję præęroçy i możliwość oświetlania ich od tyłu.

Elementy metalowe takie jak zawiasy, gwoździe - oczyszczano z produktów korozji mechanicznie i - jak odnotowano w trzech przypadkach zabezpieczano (w 1995 r. - Lańcut, Gotha, 2007 - element z Compiègne). Dokonane obserwacje wskazuja, że po demontażu płócien w celu wykonania np. ich dublażu ponowny montaż na strukturach nośnych - sztangach, krosnach - wykonywano z użyciem nowych gwoździ, czasem - jak w przypadku elementów dekoracji prezentowanych na wystawie w Gotha, konserwowanych w 1997 r. - stosując kartonowe podkładki. Dokonując napraw elementów praystawek i terenów w Lańcucie, w 1995 r., zastosowano nierdzewne wkręty. W podobnym czasie w Ludwigsburgu ponownego montażu dekoracji kulis na krosna dokonano za pomoca krajek pomocniczych, bez przybijania, rezygnując z typowego montażu. Naciag płótna na

\footnotetext{
46 V. Kern, op.cit., s. 42 oraz bezpośrednie informacje z dokumentacji konserwatorskiej uzyskane na miejscu, przekazane przez V. Kerna.
} 
krośnie tamanym, tj. składanym w prayystawce z Compiègne, poddanej konserwacji i restauracji bez demontażu z krosien, utracony w miejscu złożenia z powodu korozji gwoździ, przywrócono również nie stosując nowych gwoździ, a za pomoca rzepów doszytych do włókniny poliestrowej, która przyklejono do płótna pod listwą na międzywarstwę z bibuły japońskiej.

W zakres wczesnych interwencji (z lat 60.-70., Český Krumlov, Litomyšl) nieodzownie wchodził dublaż, zwłaszcza elementów zwieszanych. Z krótkiej relacji odnoszącej się do tych pierwszych prac wynika, że był to zasadniczy, jeśli nie jedyny zabieg dotyczący płóciennego podłoża dekoracji. Dlatego zdecydowano omówić go tu w pierwszej kolejności. Dublaż dotyczący głównie prospektów i w tamtym czasie prócz wzmocnienia zdegradowanego płótna miał zapewne na celu zniwelowanie deformacji poprzez usztywnienie podłoża. Brak pewnych danych dotyczących używanego spoiwa. W Českim Krumlovie stosowano je z bolusowym wypełniaczem, przesycając masa płótna dublażowe. Skład masy dublażowej używanej w podobnym okresie w Litomyšlu nie jest znany. Również i tam usztywnienie podłoża oraz charakter zniszczeń, które spowodowała w późniejszym czasie każe przypuszczać, że cechowała ją duża reaktywność w zmiennych warunkach wilgotności, czyli zawierała prawdopodobnie kleje glutynowe.

W okresie późniejszym, w latach 80. w Českim Krumlovie wykonując dublaże zastosowano cieńszy, bawełniany nośnik, a jako spoiwo dublażowe dyspersję akrylowo-styrenową i pokryto odwrocia farba - w efekcie też otrzymując sztywny układ. W kolejnej kampanii konserwatorskiej przeprowadzonej w tej samej kolekcji w 2. połowie lat 90. do 2005 r. elementy na krosnach i sufity dublowano już z użyciem merli introligatorskiej i metylocelulozy z dodatkiem dyspersji akrylowej. Usunięto dawny dublaż z partii pręerrocyy. Jednak w niektórych przypadkach zdublowano całościowo płótna kulis zawierających praktykowane otwory w postaci okien, pozbawiając je tym samym tej funkcji. W podobnym czasie w Litomyšlu usunięto dawne dublaże prospektów.

W ramach zabiegów konserwatorskich w innych kolekcjach nie przeprowadzano całościowych dublaży płóciennego podłoża dekoracji. Dokonujacc, modelowej w zamyśle, restauracji kulisy w Lambach (1999), osłabione fragmenty płótna, w strefach ubytków zdublowano włókniną poliestro- 
wą z naniesiona na nią błoną uzyskaną z dyspersji akrylowej ${ }^{47}$, podobnie zostały zabezpieczone osłabione fragmenty prospektów w Compiègne, z zastosowaniem dodatkowej międzywarstwy z gazy i w prospekcie Lasu w teatrze Marii-Antoniny w Wersalu $(1996,2006)^{48}$. Osłabiony fragment płótna w przystawce z Compiègne, konserwowanej w latach 2006-2007, zdublowano, naklejając od odwrocia warstwę papieru japońskiego na klej skrobiowy ${ }^{49}$. Podczas konserwacji-restauracji kulis kolekcji z Ludwigsburga (1987-1995) wykonano dublaż krajek, stosując jako spoiwo dyspersję akrylową i dla całości zastosowano „luźny dublaż”, napinając na krosna, przed zamontowaniem na nie płócien dekoracji, warstwę nowego płótna. Oryginalne płótno przytwierdzono, nie używając gwoździ, a mocując zdublowane krajki za pomoca spoiny z błony uzyskanej z dyspersji akrylowej. Dublaż krajek dwiema warstwami włókniny poliestrowej, w celu umożliwienia ponownego naciagu na krosna zastosowano podczas ratunkowej kampanii konserwatorskiej w Compiègne, w 1996 r. W prospektach kolekcji z Meiningen, w latach 1995-1999, zdublowano tylko zniszczone fragmenty tuneli na sztangi, a uzupełnienia płótna zdublowano gaza jedwabną, stosując Bevę 371. W Gotha wykonano „szkieletowy” dublaż kurtyny pasami płótna z użyciem tego samego spoiwa ${ }^{50}$. W zwieszanych elementach dekoracji w Łańcucie zdublowano ich górne krawędzie w „sandwich”, stosując jako spoiwo dyspersję akrylową a uszkodzone fragmenty płócien w obrębie sylwet na praystawkach zdublowano płótnem przyklejonym do podłoża ze sklejki klejem z dyspersji polioctanowej. W Lambach zdublowano krajki płótna tkaniną bawełniana, stosując dyspersję akrylową. Same tylko krawędzie płócien elementów zbudowanych na krosnach z kolekcji w Fontainebleau, w 2002-2004, zostały zdublowane w celu ułatwienia korekty naciagu płócien.

47 J. Ortner, op.cit., s. 314.

$48 \mathrm{~V}$. Trémoulet, L'intervention de sauvetage d'une partie du fonds des décors de scène du petit théatre Louis Philippe du château de Compiègne, [w:] Arts du spectacle: collections patrimoniales et documentation, XXIII Congrès International, Société Internationale des Bibliothèques et des Musées des Arts du Spectacle, Paris, 2530 Septembre 2000, BNF, Paris, 2002, s. 119 oraz dane uzyskane bezpośrednio.

49 C. Bringuier, op.cit., s. 133, 134.

${ }^{50}$ V. Kern, op.cit.; S. Timm, op.cit. 
Reperacje płócien dokonywane podczas pierwszych kampanii konserwatorskich, z lat 60. i 70. nie są opisane. Podczas pierwszych zabiegów konserwatorskich wykonanych na kulisach jednej z dekoracji w Kortrijk, w latach 80. XX wieku na rozdarcia naklejono od odwrocia płócienne łaty, najprawdopodobniej przy użyciu ogólnodostępnej dyspersji polioctanowej. W latach 80. do początku 90. dokonując konserwacji-restauracji jednego z prospektón w Litomyšlu i kulis w Českim Krumlovie, stosowano cienkie bawełniane łaty z bandaży, w tym ostatnim przypadku używając spoiwa z mieszaniny metylocelulozy z dyspersja akrylowa. Podczas kolejnej kampanii w Českim Krumlovie w 2. połowie lat 90. do 2004, łaty płócienne wmontowywano na styk w miejscach ubytków już po dokonaniu dublażu. Podobnie, od lica, wklejane były uzupełnienia ubytków w Gotha, w 1997. W Lambach wklejano w ubytki płócienne łaty, stosując mieszaninę kleju króliczego z metyloceluloza. Podczas ratunkowej kampanii konserwatorskiej w Compiègne w 1996, w miejsce ubytków płócien wklejono podwójna warstwę włókniny poliestrowej, używając spoiwa z zagęszczonej dyspersji akrylowej. Podczas konserwacji-restauracji dekoracji teatralnych w Ludwigsburgu łaty płócienne w ubytkach umocowano metodą stosowaną w konserwacji tekstyliów (przepikowano nicia). Podobnym sposobem zszywając - połączono brzegi rozdarć. W zbliżony sposób wzmocniono krawędzie rozdarć w jednym z prospektón poddanych konserwacji zachowawczej w Compiègne w ramach kampanii ratunkowej w 1996 r. ${ }^{51}$ Podczas prac konserwatorskich i restauratorskich dokonywanych na części kolekcji z Fontainebleau w 2002-2004 brzegi rozdarć sklejono na styk. W praystawce-fermie z kolekcji Compiègne konserwowanej i restaurowanej w latach 2006-2007 reperacji płótna dokonano metodą mostkowania nitkami wklejanymi na stałe mieszanina kleju rybiego (jesiotrowego) ze skrobiowym i przetykając pomiędzy „mostkami” pojedyncze nitki ${ }^{52}$.

O likwidowaniu deformacji płócien w elementach zwieszanych mało jest wzmianek. Elementy poddawane konserwacji w Českim Krumlovie pod koniec lat 90. do 2004, były rozpinane na podłodze podczas zabiegu dublowania, naciag i wilgoć oraz wysychanie spoiwa powodowały niwelowa-

\footnotetext{
51 V. Trémoulet, L'intervention..., s. 120.

52 C. Bringuier, op.cit., s. 132-133.
} 
nie odkształceń płócien. W przypadku prac wykonanych w Gotha, w 1995 roku, odnotowano „prostowanie przez nawilżanie”, a w tym samym czasie w Lańcucie - nawilżenie i prasowanie.

Siatki tapicerskie, stosowane od XIX wieku do stabilizacji ażurowych wycięć fartuchów i przeciéć, znajdowały się w zestawach dekoracji z Meiningen i Łańcuta, które zostały poddane zabiegom konserwatorskim i restauratorskim w latach 1995-1999 i w 1995 roku. W pierwszym wypadku rozdarte siatki wiązano i część zastąpiono nowymi, odpowiednio je barwiąc, w drugim - dokonano wymiany podartych siatek.

Niewiele jest informacji na temat traktowania papierowych osłon płócien - maruflażu odwroci. W przypadku płócien kulis, w kolekcjach czeskich poddawanych od lat 60. dublażowi trudno dziś osądzić, czy wyposażone były pierwotnie w papierowe osłony. Możliwe, że podczas pierwszych kampanii konserwatorskich ich katastrofalny stan oraz nieświadomość faktu, że stanowią integralną część kulis i innych elementów dekoracji budowanych na krosnach przesądziły o ich usunięciu. Nie można wykluczyć, że nie stosowano ich w ogóle - jak najprawdopodobniej miało to miejsce w przypadku kulis z Ludwigsburga. Hipotez tych dziś nie można potwierdzić. Kwestie konserwacji papierowych osłon odwroci dotyczą tylko części opisywanych kolekcji. Podczas konserwacji XVIII-wiecznych elementów zbiorów w Fontainebleau część papierów wymieniono, pozostałe po oczyszczeniu zostały ponownie naklejone na odwrocia. Podczas konserwacji praystawki z Compiègne papiery osłon zostały po oczyszczeniu na sucho zdemontowane, poddane kapieli dezynfekującej, zdublowane na bibułę japońska, Tyloza a następnie naklejone na odwrocie po uprzednim naklejeniu na nie, na metylocelulozę, przekładek z papieru japońskiego ${ }^{53}$. W Lambach w światło krosna kulisy poddawanej konserwacji wstawiono od odwrocia płyty piankowo-kartonowe, punktowo przyklejając je dyspersją akrylowa. Ta osłona ma pełnić funkcję podobną do tradycyjnie stosowanego w takich elementam papierowego maruflażu, usztywniającego ni zarazem zapobiegającego prześwitywaniu, lecz jest gruba $(1,5 \mathrm{~cm})$.

53 Ibidem, s. 137-143. 
Brak jest pewnych danych o środkach stosowanych do konsolidacji warstw leżących na płótnie, do lat 80. włącznie. W okresie późniejszym, w latach 90. odnotowano równolegle stosowanie spoiw na bazie pochodnych celulozy (Tylozy i Klucelu) oraz kleju glutynowego - rybnego, jesiotrowego. Pierwszą z substancji stosowano podczas konserwacji-restauracji elementów na krosnach w Českim Krumlovie w 2. połowie lat 90. do 2004 r., z dodatkiem dyspersji akrylowej, drugą - dokonując konserwacji-restauracji kulis w Ludwigsburgu oraz w Meiningen (1987-1994 i 1995-1999), w Lambach (1999) i podczas zachowawczej konserwacji zbioru dekoracji w Compiègne w 1996 r., a klej jesiotrowy w Gotha, w 1995 r. Jednocześnie do tego celu, w podobnym czasie, w 1995 r. w Lańcucie użyto żywicy akrylowej w rozpuszczalniku - Paraloidu B-72. W okresie późniejszym, już w obecnym wieku, odnotowano stosowanie w celu konsolidacji klejów naturalnych, podczas zabiegów przeprowadzanych we Francji i w Belgii - podczas konserwacji-restauracji części kolekcji z Fontainebleau w 2002-2004 (klej „naturalny”, nieokreślony) oraz klej jesiotrowy i tenże w mieszaninie ze skrobiowym (z Jin-Funori) w 2007 r. dla praystawki z Compiègne, klej skórny króliczy zastosowano w 2011 r. podczas zabiegów na dekoracjach z kolekcji Teatru Marii-Antoniny i żelatynę techniczną w Kortrijk w 2013 r.

Uzupełnienia warstw leżących na płótnie w sposób najbardziej widoczny świadczą o tym, jaki punkt widzenia przyjmowano, dokonując restauracji iluzjonistycznych dekoracji teatralnych. Podobnie jak w przypadku wcześniej opisywanych zabiegów, nie ma informacji o rozwiązaniach zastosowanych w tym zakresie podczas najwcześniejszych interwencji konserwatorskich dotyczących kolekcji dekoracji teatralnych, prócz wzmianki o wykonaniu „lokalnych retuszy” w trakcie prac prowadzonych w Českim Krumlovie w latach 70. XX wieku ${ }^{54}$. W latach 80., podczas kolejnej kampanii konserwatorskiej dotyczącej kulis tej kolekcji, zastosowano uzupełnienia kitem kredowo-klejowym i punktowania „rozpuszczalna tempera”, metoda trattegio. Podczas kolejnych interwencji, w latach 90. do 2004 r., wykonano scalanie akwarelami mieszanymi ze spoiwem używanym do konsolidacji

54 V. Zemanová, H. Klouda, Restaurováni..., s. 60. 
(roztworem Tylozy z dodatkiem dyspersji akrylowej). W podobnym okresie w Gotha do scalenia ubytków warstwy malarskiej zostały użyte gwasze ${ }^{55}$. Podczas dokonywanej w latach 1995-1999 konserwacji-restauracji dekoracji z Meiningen uzupełnień dokonano wyłącznie w miejscach długich zadrapań farbami klejowymi. W poddawanej zabiegom konserwatorskim w latach 1987-1995 kolekcji dekoracji z Ludwigsburga nie wykonano w ogóle uzupełnień warstw leżących na płótnie.

Dekoracje z teatru dworskiego w Lańcucie konserwowane i restaurowane w 1995 r. uzyskały uzupełnienia warstw zaprawy kitem kredowo-klejowym z izolacją akrylową z Paraloidu B-72 ze środkiem biobójczym, a scalenia kolorystycznego dokonano farbami z pigmentów mieszanych z polialkoholem winylu. Uzupełnienia miały charakter imitacyjny, w partiach silnie zniszczonych dokonano praktycznie malarskiej rekonstrukcji. W Lambach (1999) wykonano barwne uzupełnienia cienkiej warstwy malarskiej bezpośrednio na płótnie, pigmentami z roztworem polialkoholu winylu. W Litomyšlu, podczas konserwacji jednego z zestawów dekoracji w 2003 r. wykonano uzupełnienia zaprawy handlowym kitem akrylowym, a punktowania pigmentami ze spoiwem z Paraloidu B-72. Z kolei podczas prac przeprowadzanych na XVIII-wiecznych elementach kolekcji z Fontainebleau w latach 2002-2004 uzupełnienia ograniczono do złagodzenia przetarć i plam zacieków, wykonując je głównie suchymi pastelami w sposób pozwalający je odróżnić od oryginału z bliskiej odległości ${ }^{56}$. W praystawce z Compiègne, poddanej zabiegom w latach 2006-2007, uzupełnienia zostały ograniczone do barwnego scalenia $z$ otoczeniem dodanych fragmentów - cienkich fleków z balsy w szczelinie sylwety i widocznych od lica nitek uzupełnień płótna - czego dokonano pigmentami z roztworem Klucelu. W ostatniej z relacjonowanych konserwacji-restauracji dekoracji teatralnej z Kortrijk, ukończonej w 2013 r., na kulisach zakładano lokalnie kity, a uzupełnienia i retusz w partiach przebarwionych zaciekami wykonano kredkami pastelowymi, utrwalonymi napyloną warstwą Paraloidu B-72.

Miarodajna ocena trwałości i efektywności na dłuższą metę poszczególnych zastosowanych rozwiązań konserwatorskich i restauratorskich wymaga-

\footnotetext{
55 S. Timm, op.cit., s. 122.

56 V. Trémoulet, Conservation et restauration..., s. 89.
} 
łaby bardziej szczegółowej analizy przeprowadzonej po upływie podobnego okresu czasu we wszystkich kolekcjach. Podczas przeglądu wybranych elementów kolekcji poddanych zabiegom możliwe było jedynie potwierdzenie ograniczonej skuteczności zabiegu niwelowania poprzez prasowanie deformacji elementów zwieszanych, konieczności regularnej reaktywacji spoin akrylowych zastosowanych do montażu płócien kulis (w Ludwigsburgu) i zaobserwowanie, że wybór materiałów użytych do uzupełnień warstw malarskich, bądź sposób ich użycia, nie zawsze gwarantują ich barwną stabilnośćs7.

\section{Podsumowanie}

Analiza przedstawionych powyżej danych pozwala dokonać interesujących spostrzeżeń dotyczących koncepcji przeprowadzanych działań konserwatorskich i restauratorskich. Zauważalne jest, że podejmując proces konserwacji-restauracji dekoracji teatralnych jeszcze w latach 90., traktowano je często jak wielkoformatowe, oddzielne obrazy sztalugowe ${ }^{58}$. Przyjęcie takiej optyki znajdowało odbicie w rezultatach tych działań, rzutujących na wartości

${ }^{57} \mathrm{~Np} . \mathrm{w}$ przypadku niektórych odcieni akwarel mieszanych z dyspersją akrylowa. Zastosowanie kredek pastelowych Derwent w ostatnim z cytowanych przykładów nie gwarantuje trwałości uzupełnień zwłaszcza w partiach rozjaśnianych, co każa przewidywać informacje opublikowane przez producenta [http://www.pencils.co.uk/product.aspx? $\mathrm{mid}=725$ (20.08.2013)], światłotrwałość zestawu oscyluje między 3 (bardzo niska) a 8 (wysoka), w przypadku niektórych odcieni, zwłaszcza najjaśniejszych, jest niestety niska.

58 Wyrazem takiej tendencji były przeprowadzane konserwacje-restauracje XIX i XX-wiecznych teatralnych kurtyn, czasem, choć nie zawsze, mocowanych oryginalnie na konstrukcjach mających zapewnić naprężenie bądź sztywność podłoża i czyniące z nich „obrazy wielkoformatowe”, inspirowane też pracami dotyczącymi panoram - vide publikacje wskazane w przyp. 731 oraz Małgorzata Gursztyn, Malowane kurtyny teatralne, ich stan zachowania, przyczyny zniszczeń i wytyczne prac konserwatorskich, [kps], UMK Toruń 2007 (praca magisterska pod kier. prof. dr. hab. D. Markowskiego, IZK, UMK Toruń) i M. Kozarzewski, R. Wójtowicz, Panorama Feszty, raport z. prac konserwatorskich Ópusżtaszer, 1991-1995, „Biuletyn Informacyjny Konserwatorów Dzieł Sztuki” 1996, 3-4, s. 13-20. Trudno wskazać dokładną cezurę czasową dla zmiany optyki w odniesieniu do kolekcji dekoracji teatralnych, impuls do niej dal, jak się wydaje, odnotowany od 2. połowy lat 90. wzrost zainteresowania teatrami historycznymi z ich wyposażeniem i wynikające z niego poszukiwania. 
obiektów poddawanych zabiegom. Pojmowanie scenicznych malowideł zawierało się początkowo w podporządkowywaniu ich funkcji obrazu, wydaje się, że nie lokowano ich znaczenia w sferze związanej z funkcją elementu iluzjonistycznego zjawiska tworzonego na scenie $z$ udziałem innych, także pozamalarskich komponentów ${ }^{59}$. W konsekwencji przyjmowano rozwiązania konserwatorskie, same w sobie wybierane zgodnie z ówczesną najlepszą wiedzą konserwatorska, lecz nieuwzględniające specyfiki i roli dzieł poddawanych zabiegom, co oznaczało m.in. sztywny dublaż w przypadku elementów zwieszanych, usuwanie detali uznanych za zbędne i przypadkowe, w które wyposażone są np. krosna kulis (takich jak np. haki) warunkujacych ich zamocowanie na elementach zespolonych ze sceniczna maszyneria, dodawanie z kolei elementów tradycyjnie niestosowanych (osłony, metalowe wzmocnienia), dublaż lub/i montaż pozbawiający præęrocza lub praktykowane (czyli używane na scenie) elementy ich funkcji, uzupełnienia ubytków wykonywane w konwencji i skali malarstwa sztalugowego. Owocowało to naruszeniem integralności i autentyczności składników zestawu, czyli obiektów kolekcji i samej kolekcji w relacji do teatralnego otoczenia i funkcji. Takie podejście wynikało z nieugruntowanego jeszcze postrzegania malarstwa scenicznego jako odrębnej, swoistej kategorii, rządzącej się specyficznymi prawami i podlegającej charakterystycznym scenicznym uwarunkowaniom, wyróżniającym te malowidła również spośród innych malarskich dekoracyjnych produkcji, uwarunkowaniom niezrozumiałym, jeśli zastosować do nich jedynie perspektywę właściwą dla malarstwa sztalugowego. Podejście do malowideł będących dekoracjami teatralnymi wyłącznie jak do wielkoformatowych obrazów zaczęło ulegać zmianie ${ }^{60}$. Obecnie brany jest pod uwagę sceniczny kontekst i charakterystyczne cechy m.in. elementów zwieszanych, które powinny zachować charakter luźnego, nienapiętego płótna. Zachowanie w procesie konserwacji-restauracji wszystkich charakterystycznych cech i detali dekoracji scenicznych jest istotne nie tyl-

59 Podobną opinię wyraża czeski konserwator, zaangażowany w działania konserwatorskie dotyczące historycznych teatrów cf.- J. Bláha, Conservation, restoration..., s. 4, 10.

${ }^{60}$ Rozszerzenie wartości autentyczności z substancji i formy, techniki wykonania na relację $\mathrm{z}$ innymi elementami otoczenia i funkcję upowszechniło się dopiero od czasu poświęconej zagadnieniu autentyczności konferencji w Nara w 1994 roku - Nara Confernce on Authenticity/Conference de Nara sur l'Authenticité, Tokyo 1995. 
ko ze względu na nie same, ich wartość historyczną (także jako dokumentów określonej techniki) i wartość autentyczności poszczególnych części, ale także z respektu dla tych wartości odnoszących się do całych zestawów dekoracji, niezbędności poszczególnych elementów dla zrozumienia ich powiązań ze sceną i użyciem na niej w spektaklach z czasów powstania tych opraw scenicznych.

Asortyment materiałów stosowanych podczas konserwatorskich zabiegów ulegał stopniowym zmianom, pozwalającym na redukcję usztywnienia w przypadku dublaży elementów zwieszanych. W niektórych przypadkach przyjmowane są rozwiązania wywodzące się z technik konserwacji tkanin. Zauważalna stała się też tendencja, niejednakowo silna we wszystkich ośrodkach, niemniej czytelna, wyboru drogi mniej ingerencyjnej, ograniczenia restauracji, przeprowadzania przede wszystkim zabiegów mieszczących się w granicach konserwacji zachowawczej.

Wydaje się też, że przyjmowane obecnie rozwiązania restauratorskie, dotyczące uzupełnień w obrębie warstw malarskich są wyrazem nie tylko tej tendencji, ale także akceptacji funkcji i oddziaływania optycznego, poddawanych zabiegom malowideł, przeznaczonych do oglądania z dużej odległości i w odpowiednim oświetleniu, nieeksponującym oddzielnych obiektów, a wyraz artystyczny i estetyczny całej scenicznej malarskiej oprawy (il. 11).

\section{Summary}

Painted, illusionist stage sceneries are special pictorial works of art, both in terms of their structure, technique of execution, size, function, and the fact that the "object" in their case is not a single element but a set constituting a stage setting, the values of which are preserved in the conditions of the stage or close to the stage. This text introduces the conservation issues and shows how the material conditions and the function determine not only the state but also the value of these historic objects. The process of their recognition as worth preserving heritage is also outlined. The conservation and restoration treatments carried out so far on eleven collections are depicted in a summary emphasizing the influence of gradual recognition of the value of these specific paintings on the evolution of conservation attitudes, implying the choice of proper methods and means of conservation. 


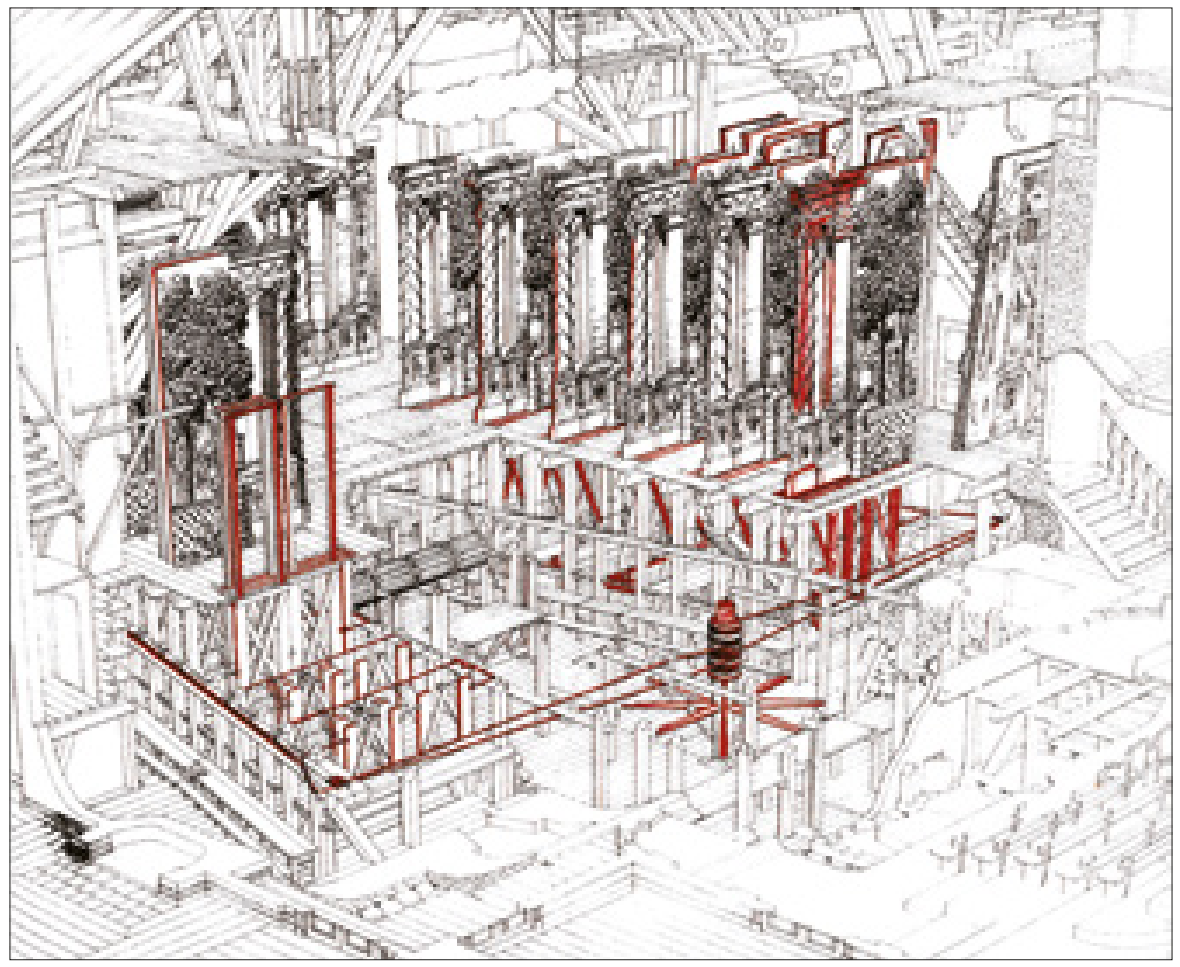

il. 1. Schemat sceny włoskiej z osadzonymi na niej elementami iluzjonistycznej dekoracji i częścią maszynerii. Czerwone podkreślenia zaznaczają naciagi i elementy wprowadzane w ruch kołowrotem (za: Drottningholms slottsteater, Dess tillkomst, öden och bevarande, Stockholm, 1993, s. 79) 


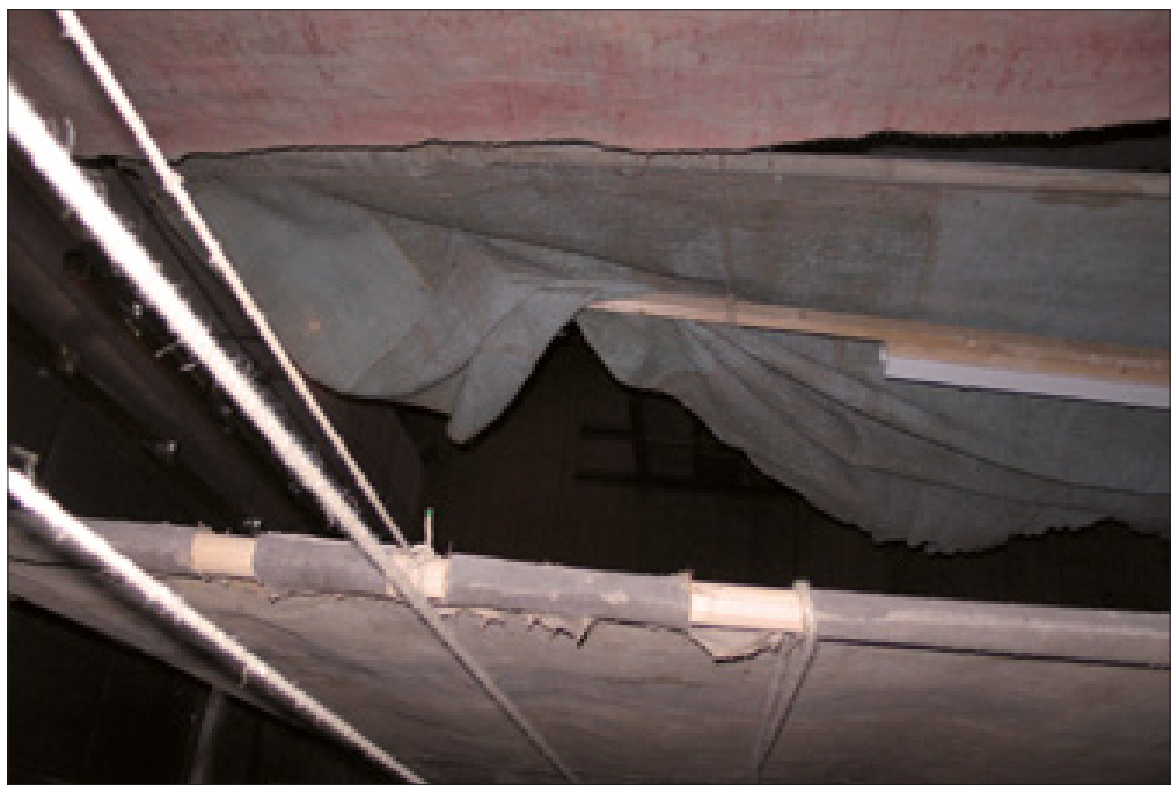

il. 2. Przypadkowe zagięcie fartucha (elementu zamykającego od góry plan dekoracji pejzażowej) na listwie oświetleniowej w trakcie żmiany otwartej dekoracji; fot. E. Szmit-Naud

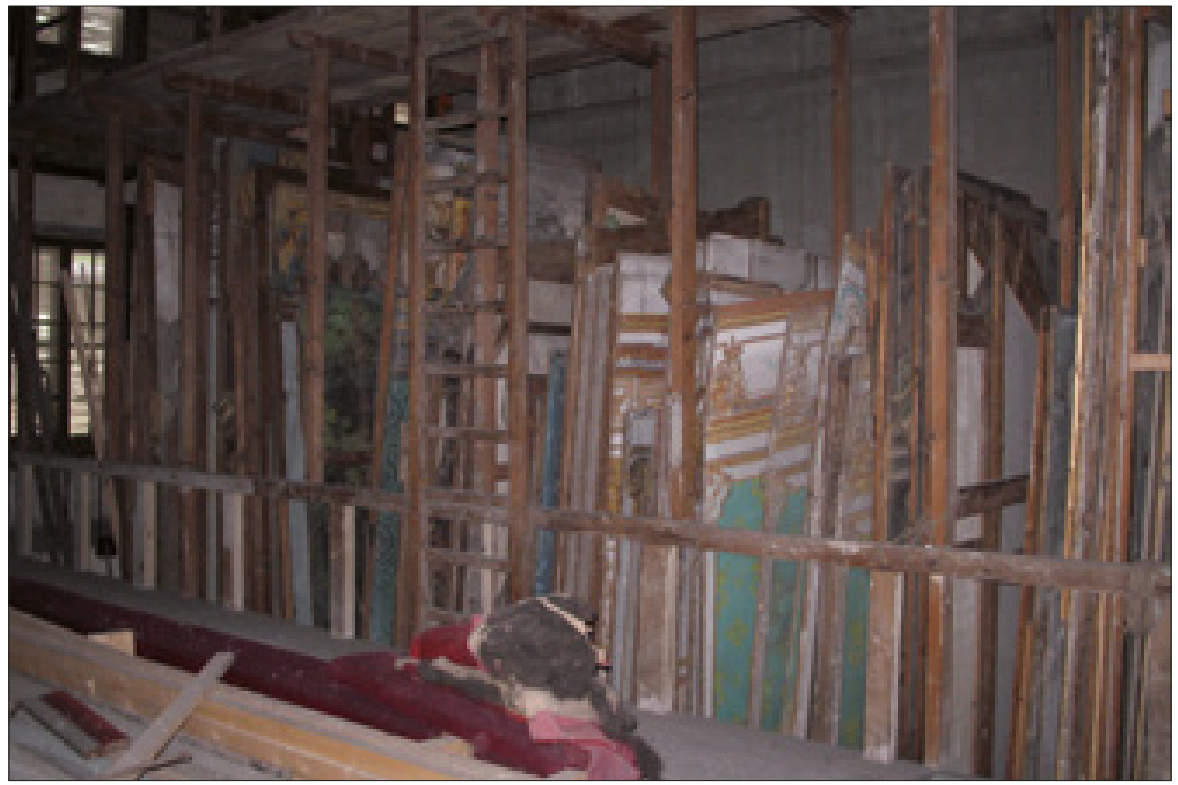

il. 3. Boksy z kulisami w zasceniu; fot. E. Szmit-Naud 


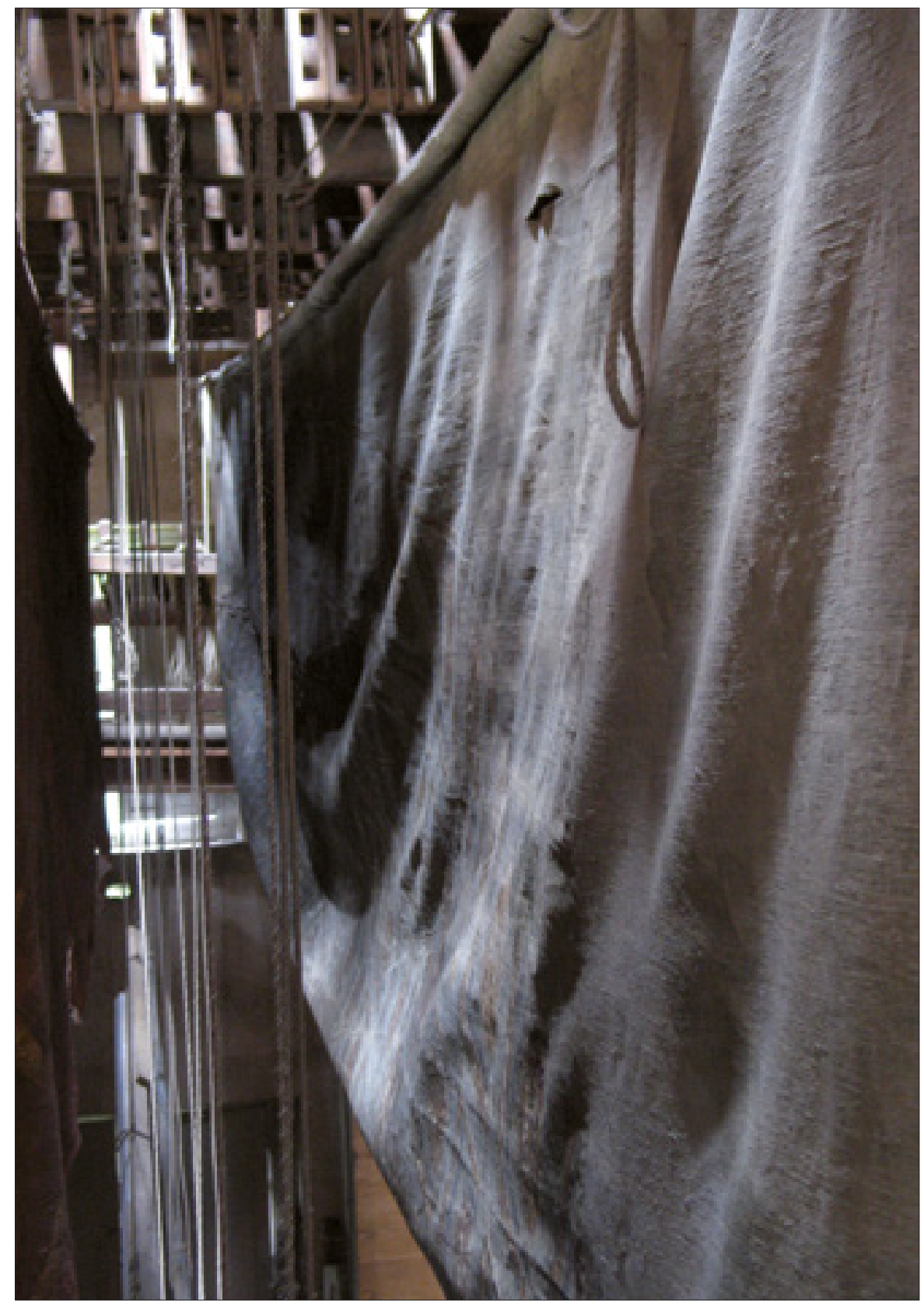

il. 4. Przykład deformacji i rozdarcia płótna prospektu zwieszonego w nadsceniu; fot. E. Szmit-Naud 


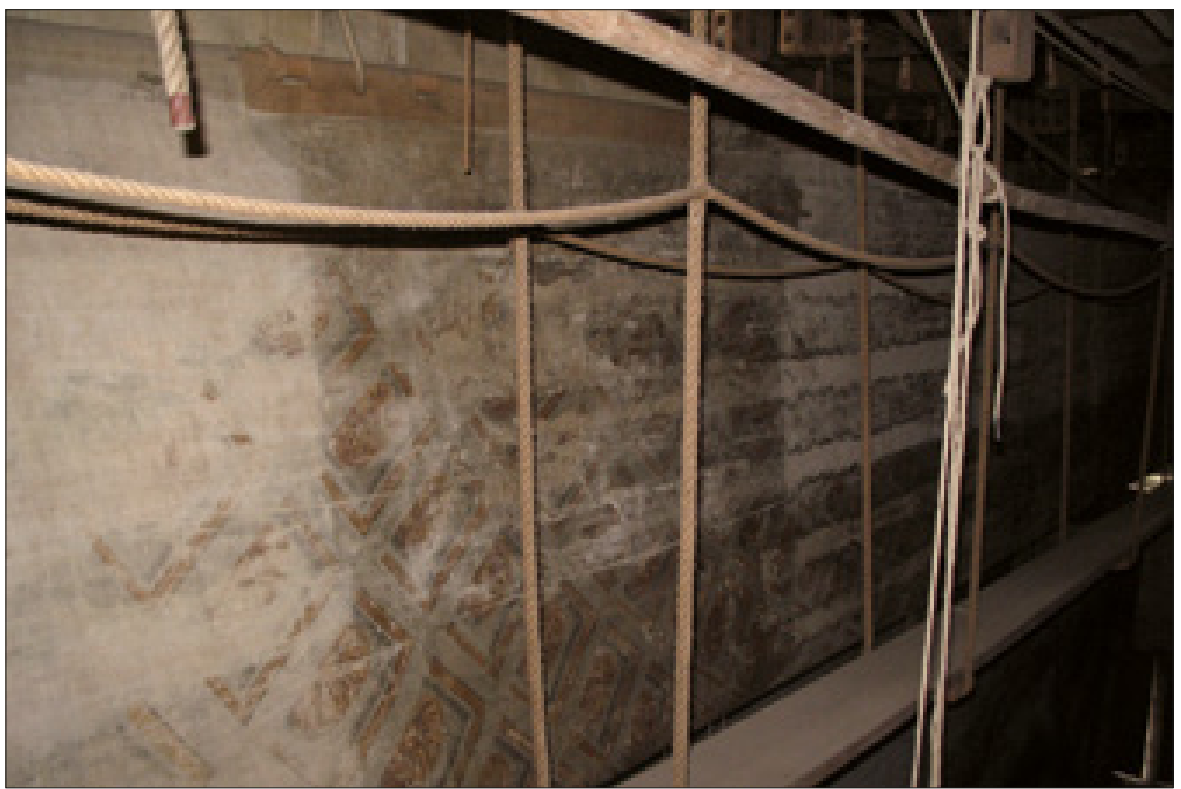

il. 5. Przykład zniszczeń warstwy malarskiej spowodowanych zwijaniem, zalaniem tłusta substancją i zamoczeniem w stanie zwiniętym; fot. E. Szmit-Naud 


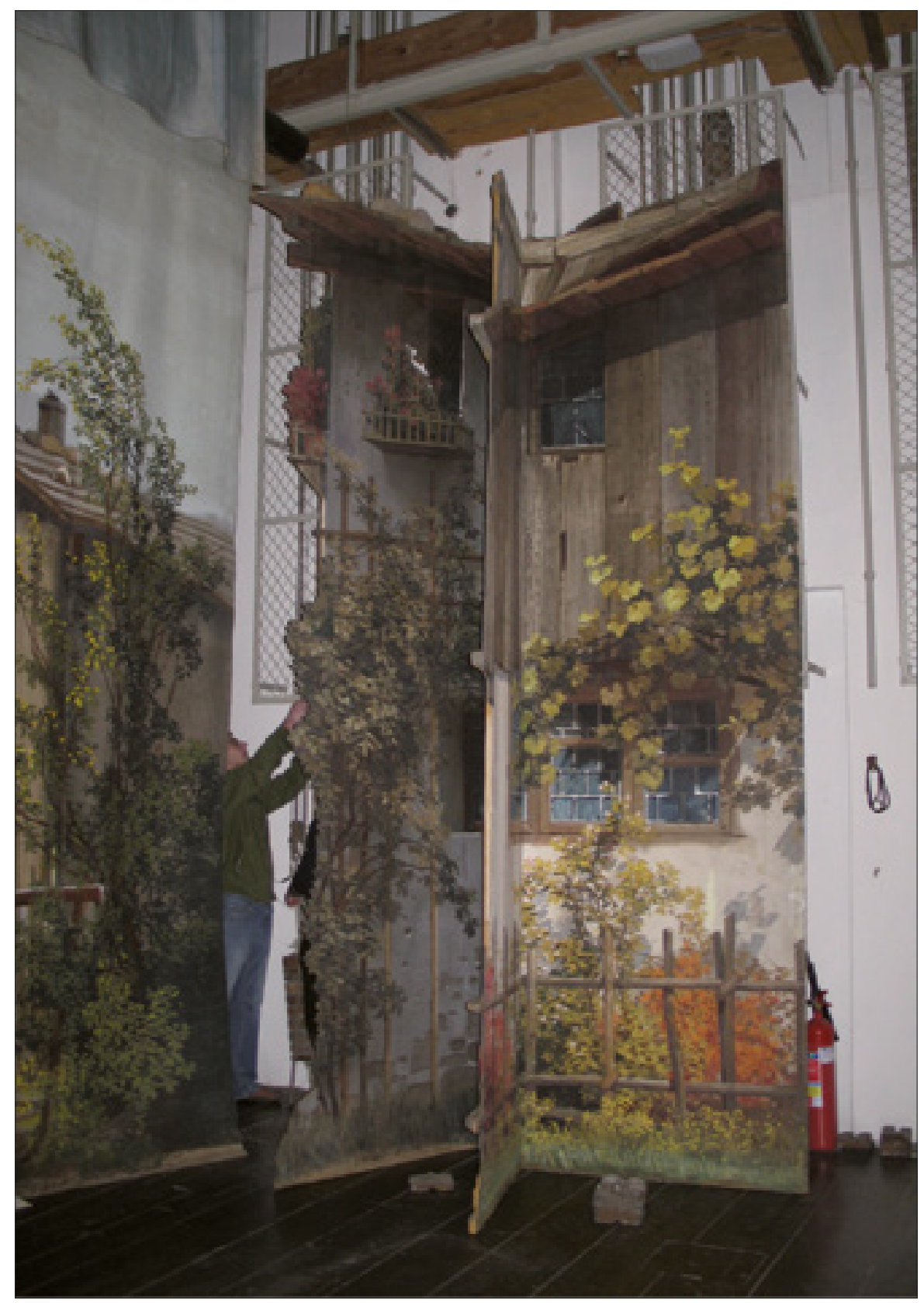

il. 6. Kulisy scenerii Wsi (in. Wioski alpejskieg) w zamkowym teatrze w Lańcucie; fot. E. Szmit-Naud 


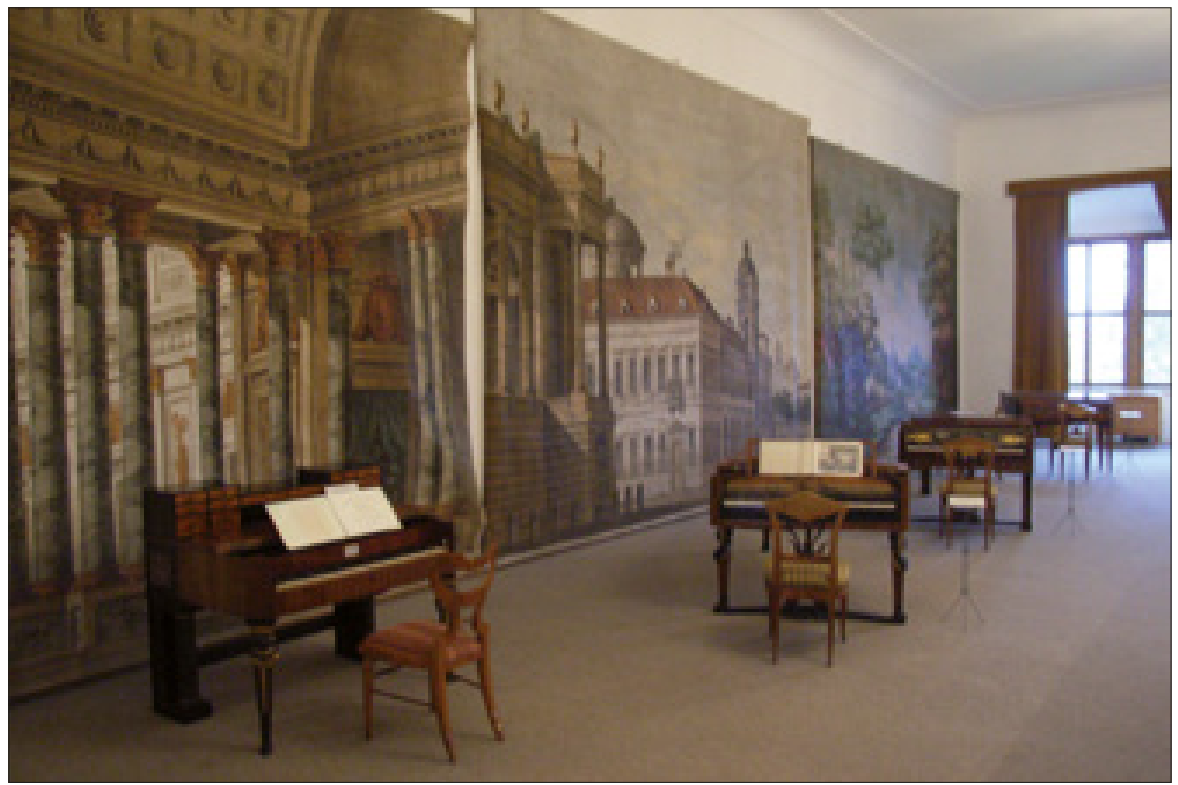

il. 7. Prospekty: Przedsionek kościoła, Ulica, Pejzaż wiejski autorstwa J. Platzera, 1797, z kolekcji zamkowego teatru w Litomyšlu eksponowane w salach Muzeum-Zamku; fot. E. Szmit-Naud

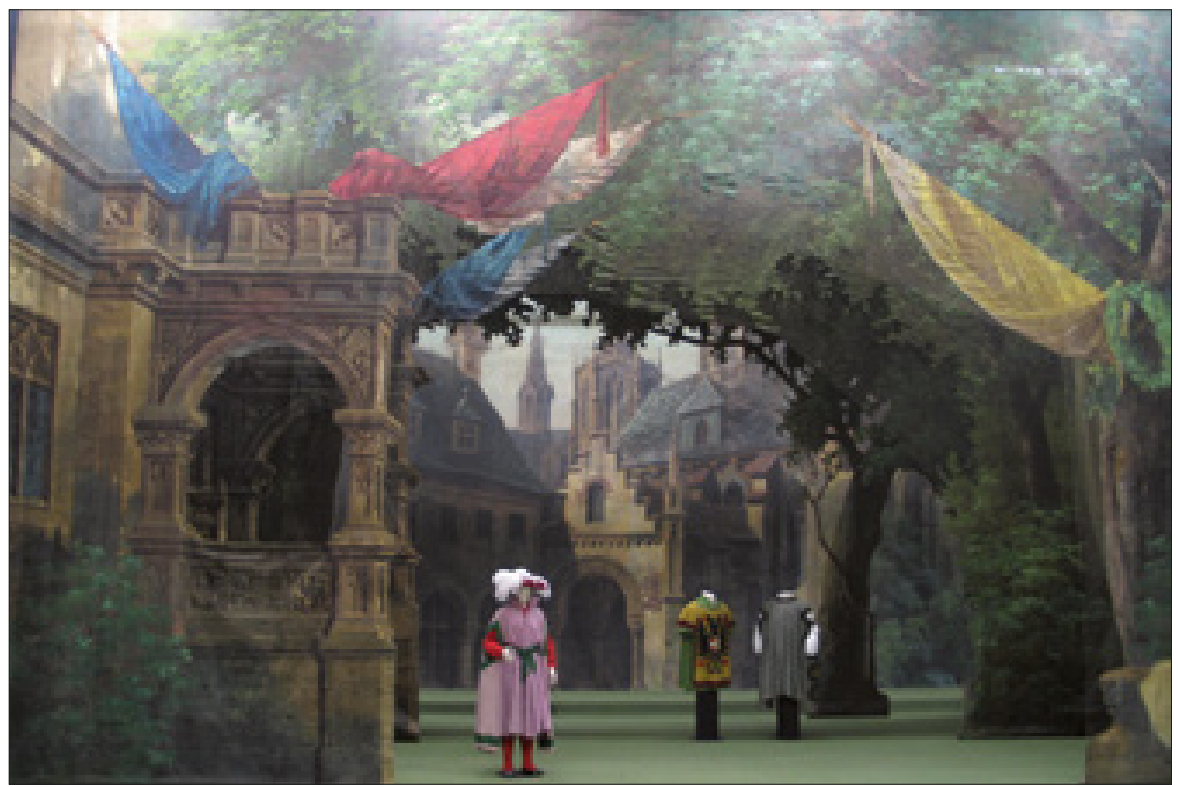

il. 8. Komplet dekoracji M. i G. Brucknerów Džiedżiniec zamkony, 1874-1890, do Kasi z Heilbronu Kleista, z teatru księcia Jerzego II w Meiningen, Muzeum Teatralne; fot. E. Szmit-Naud 


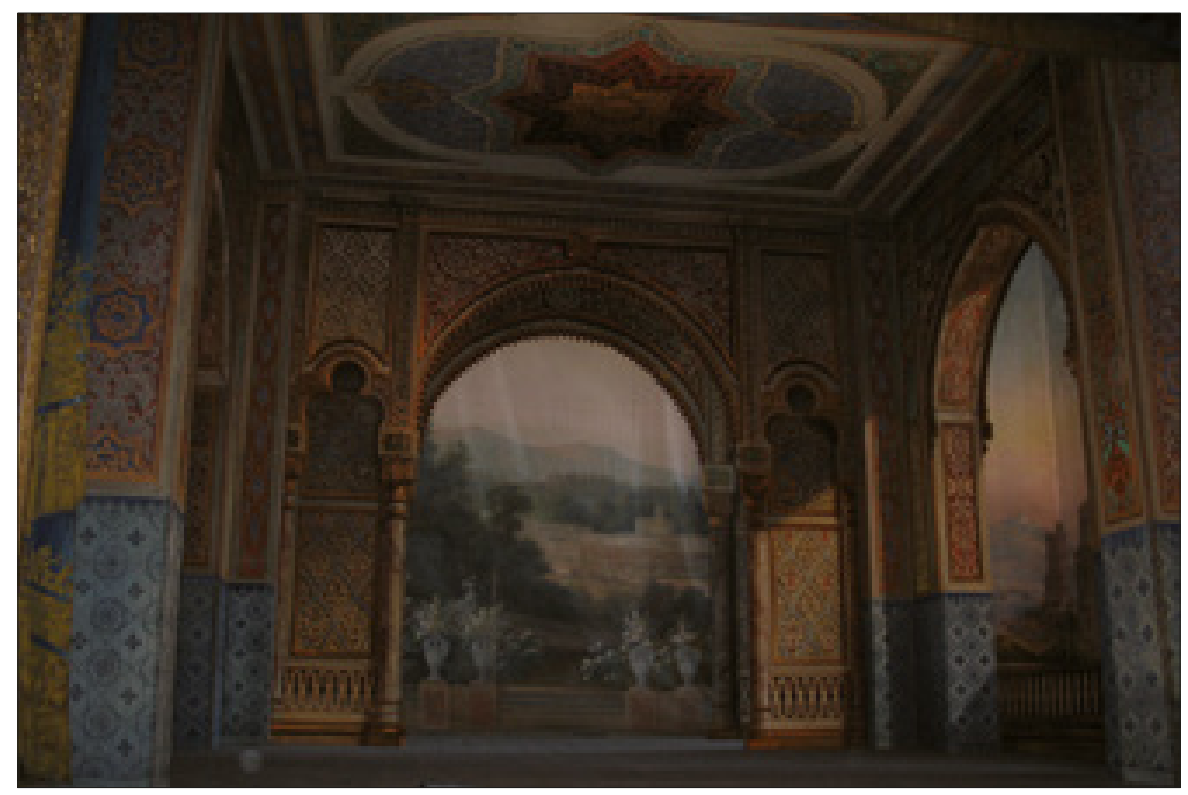

il. 9. Dekoracja Pałac Mauretański i pejzażowy prospekt, teatr Napoleona III w zamku Fontainebleau; fot. E. Szmit-Naud 


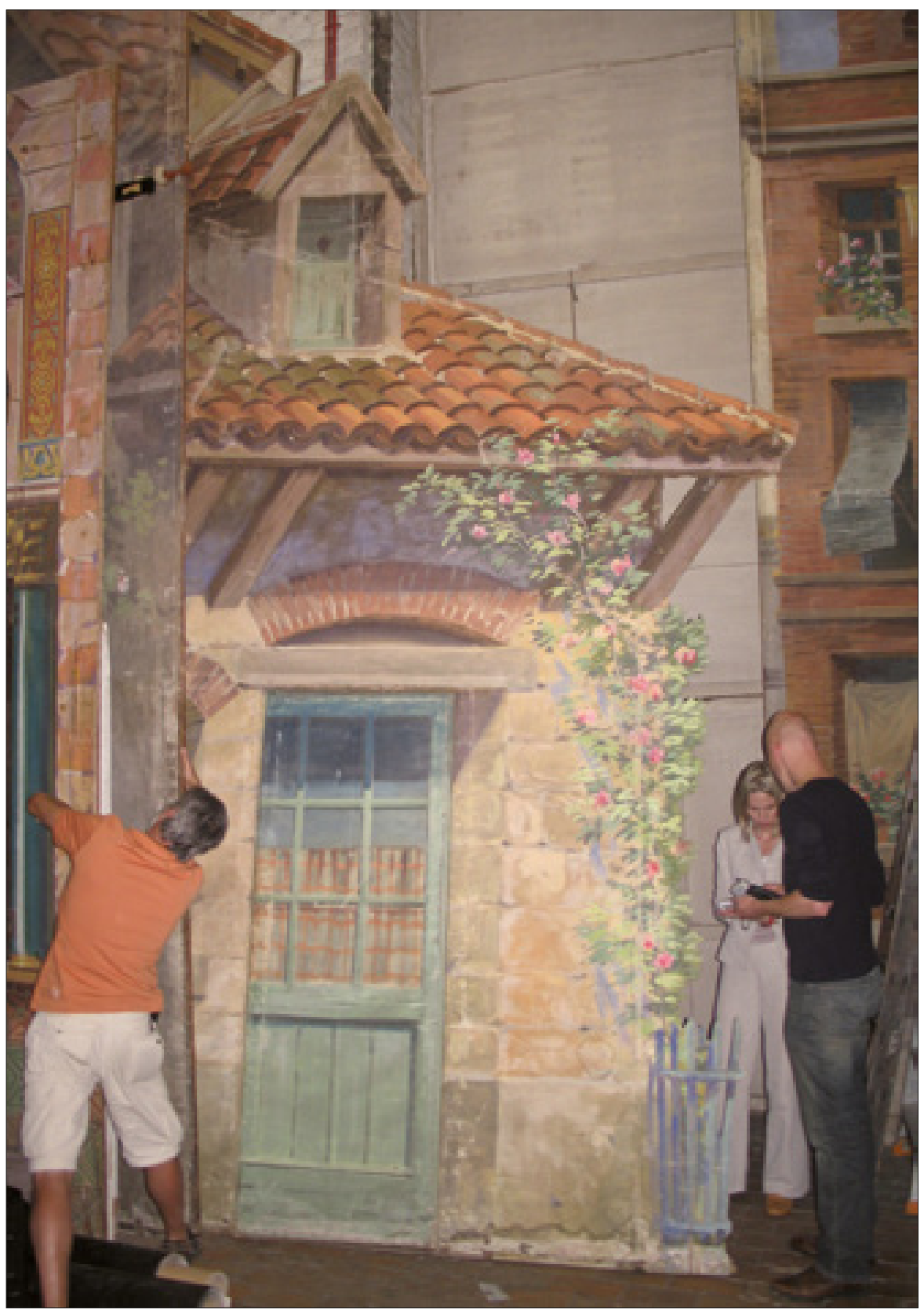

il. 10. Kulisa dekoracji Miasteczko ₹ kościotem i fragment kulisy Placu bispano-wtosko-arabskiego A. Dubosq, 1920-1923, zascenie Teatru Miejskiego w Kortrijk; fot. E. Szmit-Naud 


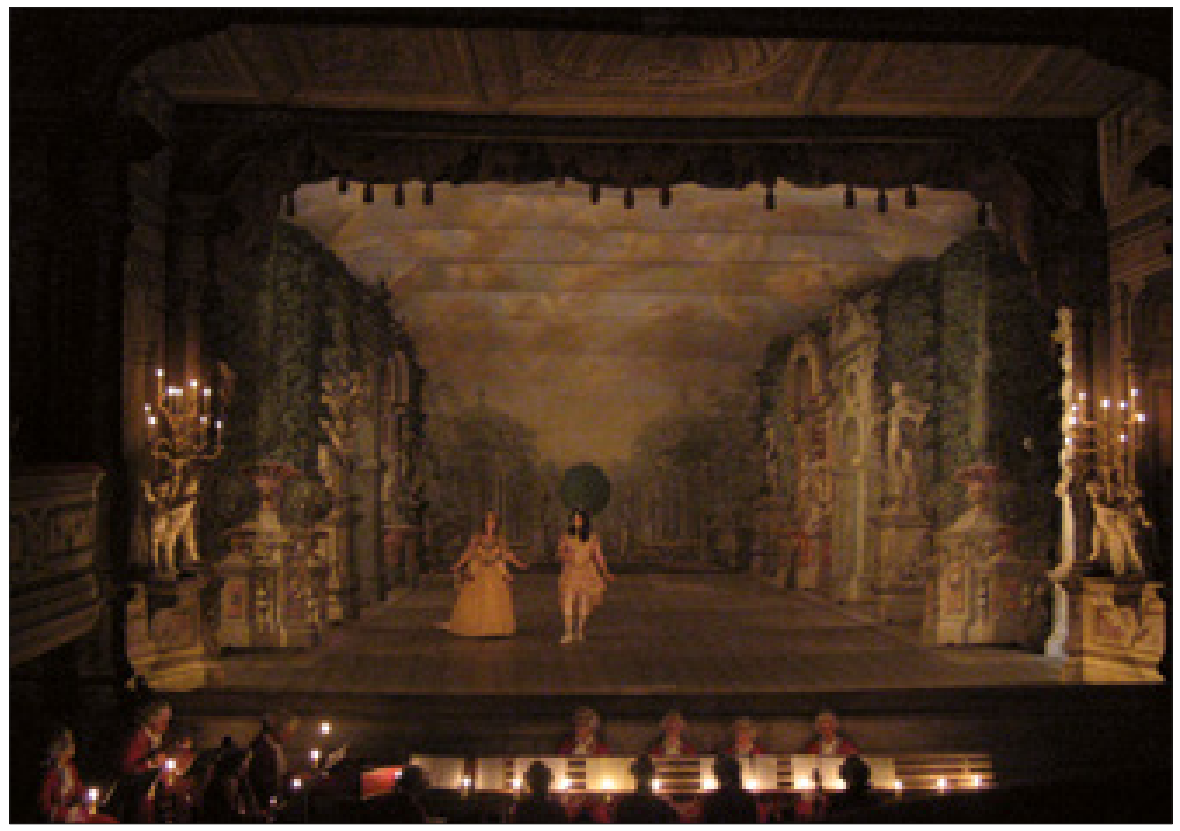

il. 11. Sceneria Ogrodu H. Wetschela i L Märkl, 1776, na scenie teatru zamkowego w Českým Krumlovie podczas eksperymentalnego wystawienia opery w ramach konferencji Świat Barokowego Teatru w 2009 roku; fot. V-A. Cremona 
